\title{
Non-Structural Flood Management in European Rural Mountain Areas-Are Scientists Supporting Implementation?
}

\author{
Felix Conitz ${ }^{1, *}$, Aude Zingraff-Hamed ${ }^{1,2, * \mathbb{C}}$, Gerd Lupp $^{1}$ and Stephan Pauleit ${ }^{1}$ (D) \\ 1 Strategic Landscape Planning and Management, School of Life Sciences, Technical University of Munich, \\ Emil-Ramann-Str. 6, 85354 Freising, Germany; gerd.lupp@tum.de (G.L.); paulei@@tum.de (S.P.) \\ 2 Interdisciplinary Research Center Cities, Territories, Environment and Society (UMR CNRS 7324 CITERES), \\ University of Tours, 37204 Tours, France \\ * Correspondence: f.conitz@tum.de (F.C.); aude.zingraff-hamed@tum.de (A.Z.-H.)
}

Citation: Conitz, F.; Zingraff-Hamed,

A.; Lupp, G.; Pauleit, $\mathrm{S}$.

Non-Structural Flood Management in European Rural Mountain

Areas-Are Scientists Supporting Implementation? Hydrology 2021, 8, 167. https://doi.org/10.3390/ hydrology 8040167

Academic Editor: Salvatore Manfreda

Received: 11 October 2021

Accepted: 27 October 2021

Published: 5 November 2021

Publisher's Note: MDPI stays neutral with regard to jurisdictional claims in published maps and institutional affiliations.

Copyright: (C) 2021 by the authors. Licensee MDPI, Basel, Switzerland. This article is an open access article distributed under the terms and conditions of the Creative Commons Attribution (CC BY) license (https:// creativecommons.org/licenses/by/ $4.0 /)$.

\begin{abstract}
Mountain areas are highly exposed to flood risks. The latter are increasing in the context of climate change, urbanization, and land use changes. Non-structural approaches such as nature-based solutions can provide opportunities to reduce the risks of such natural hazards and provide further ecological, social, and economic benefits. However, few non-structural flood mitigation measures are implemented in rural mountain areas so far. The objective of this paper is to investigate if the scientific boundaries limit the implementation of non-structural flood management in rural mountain areas. In the study, we statistically analyzed the knowledge about flood management through a systematic literature review and expert surveys, with a focus on European rural mountain areas. Both methods showed that scientific knowledge is available for decision makers and that nature-based solutions are efficient, cost-effective, multifunctional, and have potential for large-scale implementation.
\end{abstract}

Keywords: socio-ecological system; resilience; socio-hydrology; multiple correspondence analysis; risk management cycle; engineered; technical; planning; land use; land management

\section{Introduction}

Floods are natural processes in the global hydrological cycle in many terrestrial and transitional zones. They provide many regulating, provisioning, supporting, and cultural services and are crucial for the functioning and health of riverine ecosystems [1-10]. However, flooding can be a major threat to people and goods [11-13] and has become one of the most common natural hazards since 1990, especially in the Asia-Pacific region and Europe [9,13-17]. In Europe, flood risks have mainly been caused by flash floods and river floods $[18,19]$. Flood risk is characterized by the hazard (e.g., the flood amplitude), exposure (e.g., if houses are within the floodplain) and vulnerability (e.g., if houses are sensitive to flood). Flood events are characterized by factors such as the intensity of precipitation, land use, stream network and size, and catchment area size and properties, in particular slope and soil conditions [6,20-23].

Mountain areas are an important component in the hydrological system as they are water-harvesting areas [24]. Riverine floods and flash floods are by far the most common types of floods in mountain regions $[6,25,26]$. Both are mainly driven by snowmelt or ongoing precipitation. Flash floods originate from quick, heavy, and often localized rainfalls resulting in concentrated overland runoff, and riverine floods are characterized by a rising stream water level with possible bank overtopping and inundation of adjacent areas caused from excessive discharge [19]. The risk of flash floods is the highest in mountainous areas because the slopes and narrow valleys lead to high and quick runoff with high flow velocity, and the water level can rise to extreme values within a few minutes [27,28].

Changing weather patterns, hydro-morphological modifications of the rivers, and land use change such as urbanization increase both flood exposure and hazard in the entire catchment area $[6,27,29-35]$. First, climate scenarios predict that climate change 
in Europe will modify both spatial and seasonal rain events increasing the risks related to extreme weather events $[2,6,26,30,36-38]$. By 2050 and by 2080, the flood damages could be 5-fold and 17-fold, respectively, compared to 2020 [2,39]. The same studies also revealed that in mountainous regions, a greater increase in flood risks will be observed compared to lowlands. In the mountains, increased rainfall will substitute snow and ice formation [38] and consequently reduced snow and ice buffers that are particularly critical for delaying flood generation in higher mountain elevations [2]. Second, considering hydro-morphological changes, in Europe, most of the hydrological systems are altered by structural interventions to safeguard human settlements against small to medium floods, e.g., by dams [10], thus increasing risk during extreme events due to unexpected hazards in areas with high exposure and vulnerability. While rivers are natural drainage systems, hydro-morphological changes have led to dysfunctions. For example, in Germany, around $80 \%$ of the rivers Elbe and Rhine are highly modified, and $63 \%$ to $95 \%$ of wetland ecosystems are partially to completely altered $[9,40,41]$, mostly in favor of anthropogenic space such as housing and cropland [40].

Flood management (FM) can broadly be understood as the enhancement of society to cope with flood hazards, where development efforts should not increase flood vulnerability [42]. In Europe and North America, in the context of hazard reduction, risk management composed of phases such as preparedness, response, and recovery [43] is applied to decrease the disastrous impacts of flood events [42] (Figure 1). Various FM approaches exist: structural (or technical or engineered) and non-structural, including instrumental (or governance, planning, land use change, and land management) and natural measures (or nature-based solutions, NBS) [7,31]. Structural measures are, for example, flood reservoirs, instrumental measures are regulation or communication, and natural measures are, for example, reforestation and river restoration [7]. While human interventions in natural systems, especially structural measures, have often shown to be effective in flood mitigation, they often produce negative economic, social, and ecological responses [1,6,32,41,44-46]. Considering risk management, structural measures are increasingly considered controversial inducing, for example, the so-called levee effect [47]. This is characterized by a translocation and exacerbation of the risk downstream [48]. Furthermore, structural measures have often exacerbated floods [21] by increasing river's transport capacity and its flow velocity leading to bank erosion and burial in the riverbed, unstable morphology and sedimentation, poorer water quality and clarity (turbidity), and reduced hydrological and biological diversity (up to -60\%) [49]. Moreover, installation, maintenance, and repairs of structural measures can cost much more than NBS [50]. Consequently, structural measures are increasingly considered as both inadequate and insufficient [35] as well as being of economically or ecologically questionable impact [44,51,52]. Non-structural measures such as NBS are promising solutions that tackle the disadvantages of structural measures and ensure resilient FM as they are cost-efficient, multifunctional, and provide many co-benefits.

FM strategies depend on administrative, cultural, social, technical, and scientific factors. In Europe, the Flood Directive is one of the drivers of change from structural to an integrative FM approach. Integrative FM is based on non-structural measures and is increasingly implemented worldwide to tackle increasing flood risks. Despite the great need to implement non-structural FM, little has been done to design flood management based on non-structural measures as NBS [36,53-57]. Experiences in FM design have been largely made in lowlands, but upscaling measures in mountainous areas are limited because of different spatial conditions [23,58-60], having more available room to handle floodwater with features such as bigger stream channels and wider floodplains. Furthermore, little knowledge exists about FM in rural mountain areas. FM literature mainly focuses on cities and coastal areas [19,34,61-63]. FM in rural mountain areas is faced with specific challenges. The warning time for upcoming flooding is relatively short, only about a few hours $[27,61,64,65]$, reducing the effectiveness of warning systems. The narrowness, or steepness, and shallow soils limit the water storage capacity in mountains, requiring more 
and decentralized FM such as numerous small water retention basins [23,59]. Rural areas are considered to have great potential for water retention [66] but also higher vulnerability to natural hazards, fewer resources, and more need for assistance in their management [67].

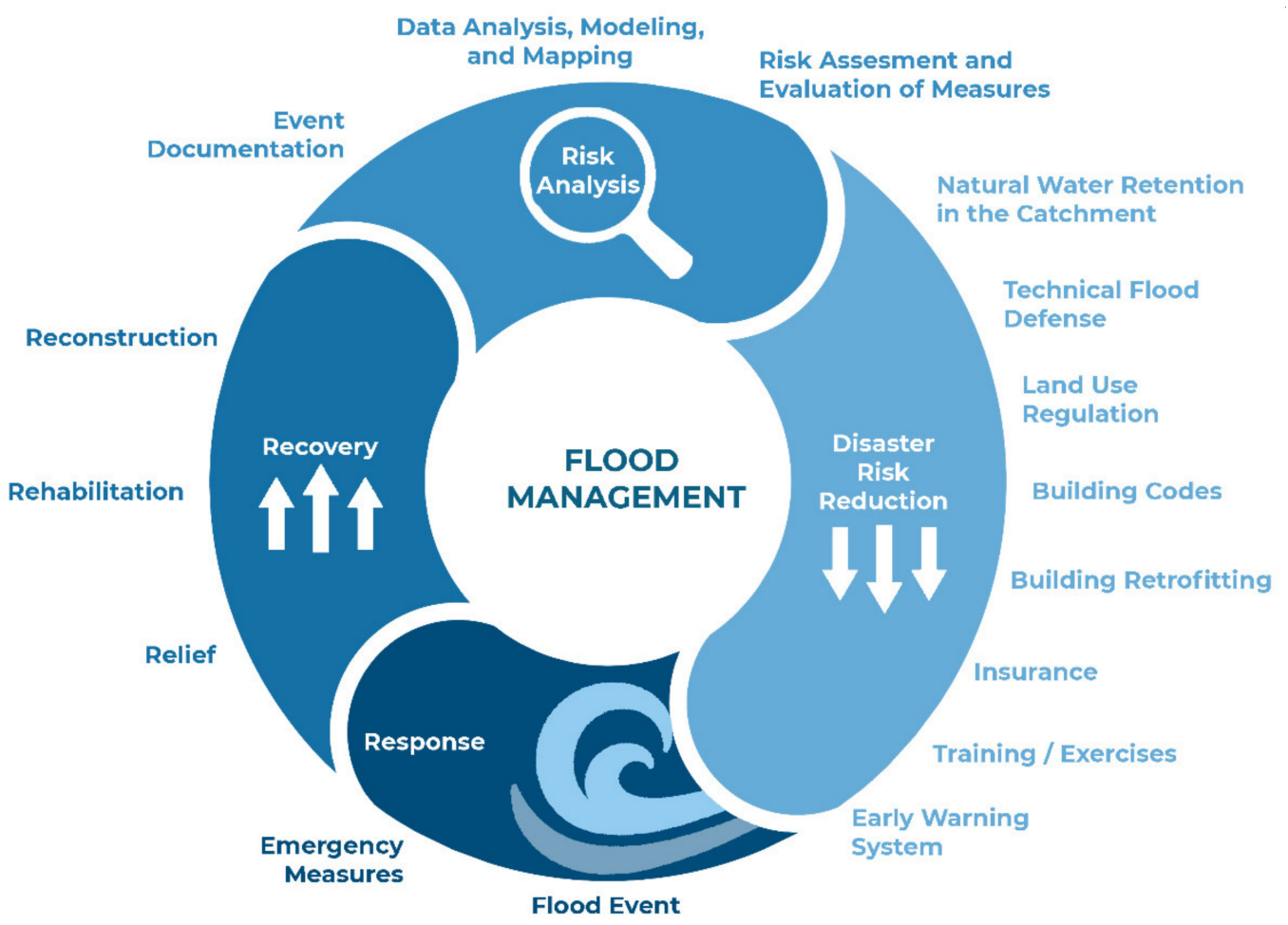

Figure 1. Management cycle in flood management (FM) inspired by [43]. Reproduced with permission from Annegret Thieken.

Implementation of FM highly depend on administrative, cultural, social, technical, and scientific boundaries. While EU legislation induces positive administrative context for non-structural FM and technical solutions exist to reduce flood risk, few non-structural projects have been implemented. Furthermore, while many studies report on FM, they focus only on single flood measures and limited locations in European rural mountainous areas (ERMA). Therefore, knowledge about the scientific boundaries remains lacking. To our knowledge, no review about the characteristics and impacts of flood measures across ERMAs has been released. However, knowing about the needs, limitations, and advantages of certain flood measures is necessary to improve current situations and adapt to future tasks. In this context, we want to answer the hypothesis of whether scientific boundaries hinder the implementation of non-structural FM in ERMA. Our study contributes to the understanding of flood measures and managements in rural mountain areas. In this context, the study's overall aim is to point out available and missing knowledge on FM in ERMAs within the scientific community by joining information from literature and expert surveys. The main objective of the study is to evaluate the accordance among literature and experts upon (1) the applicability, spatial range, and co-benefits of FM; (2) the prioritization of FM properties; and (3) preferred FM phases in ERMA. The study presents a brief overview of the state of the scientific knowledge about FM in mountainous areas, which was found to be actually encouraging rather than hindering implementations of flood measures.

\section{Materials and Methods}

The knowledge boundaries of FM in ERMAs were assessed by a systematic literature review and an expert survey followed by a comparison of both approaches, after statistical analyses (Figure 2). 


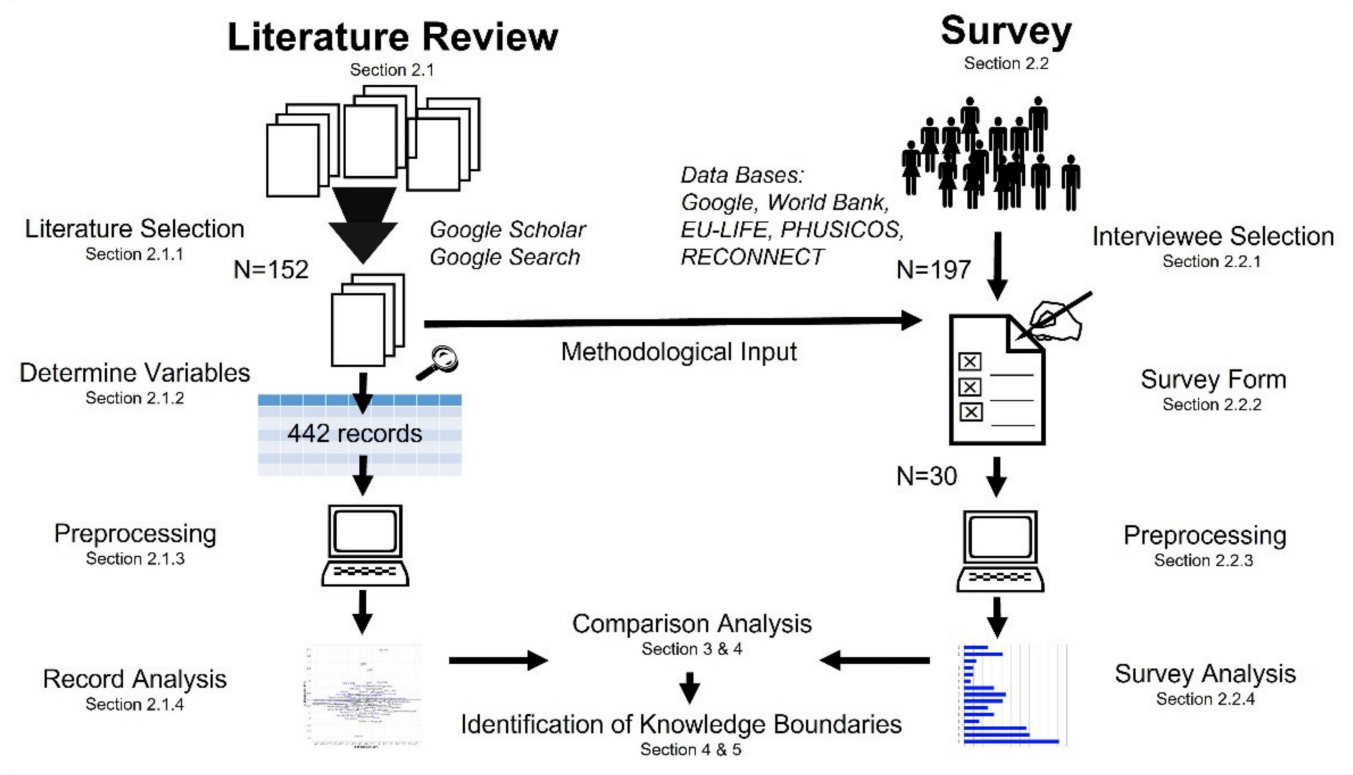

Figure 2. Methodological proceeding.

\subsection{Literature Review}

\subsubsection{Literature Selection}

A literature review on FM in mountain regions following the PRISMA method [68] was conducted using the search engines Google Scholar and Google Search with the terms "flood", "rural", "mountain", and "Europe" on 16 November, 20 November, and 2 December 2020. In total, 152 sources were selected from the first 30 pages of the search engines (600 results) through expert-based selection using systematic analyses of content of the titles and of the abstracts (Table A1).

\subsubsection{Variables}

Data were extracted from the text during reading and entered in factsheets for further analysis (Table 1, Supplementary Material S3). If a data source dealt with several measures, these were evaluated individually and only once per source, considering similar expressions for measures. All or same modalities were noted for all individual evidence if global statements or no differentiation were done, respectively. Evidence about indirect flood control, e.g., with a negative effect on flood occurrence (e.g., soil sealing) [69-72], the reverse was annotated [49,73], e.g., soil protection.

Table 1. List of flood management (FM) solutions used in the expert survey and literature description, with abbreviations and examples in brackets.

\begin{tabular}{cr}
\hline List of Variables & \multicolumn{1}{c}{ Modalities } \\
\hline Continents [Subregions] ${ }^{1}$ & $\begin{array}{c}\text { Global *, [East, South, West, and North] Asia, Australia, [East] Africa, } \\
\text { [North, South, and Central] America, [Central, East, South, West, and } \\
\text { North] Europe, Missing }\end{array}$ \\
\hline Period of Year & 1981_1999, 2000_2009, 2010_2015, 2016_2021, Missing \\
\hline Measure Block ${ }^{2}$ & $\begin{array}{c}\text { Non-structural, Nature-based, or Natural (NAT); Structural, Technical, or } \\
\text { Engineered (ENG); Instrumental (Governance (GOV), Land use \& land } \\
\text { management (LULM), Urban and rural planning (URP)) }\end{array}$ \\
\hline
\end{tabular}


Table 1. Cont.

List of Variables

Measures ${ }^{2}$

[wording in literature analysis]

NAT: Environmental and ecological preservation or [Nature conservation],

Water catchment area restoration (rewetting, rewilding, temporal flooding of areas) or [Watershed restoration], Terrestrial ecosystem and habitat restoration (drylands, wetlands) or [Ecosystem restoration], River restoration (Living River Strategy, Room for the River), Sponge vegetation restoration (replanting woods, bushes, reed zones);

ENG: Water catchment area modifications (terracing, relocation of embankments) or [Watershed modifications], River modifications (grand ox, dredging, channeling, BioGrout, walls, dams, levee, sleeper, protection from log jam), Soft flood water retention (polder, swale), Constructed water retention (water retention basin, reservoir, or pond), Water retention slowdowns and drainage systems (weirs, sluice, bypasses, throttle, sewer tunnel, siphon, pumping systems) or [Water drainage Systems],

Mobile embankments ** (sandbags, TubeBarrier, Water-Gate); URP: Flood-adapted infrastructure (bridges, railway dams, pedestrian dams, vehicles, boats), Flood-adapted architecture \& dry or wet building (stilt house, architrave block house, water shutter, adobe walls, fences);

LULM: Diverse and heterogenous land management (land use planning, zoning, subdivision ordinance, land acquisition), Managed retreat

(e.g., translocation of settlement), [Flood-adapted] Lifestyle and livelihood (up-and-downhill migration, agriculture, aquaculture, fishery, water retention), Flood-based farming (paludiculture, (rain) water resource management, inundation canals, depression agriculture) or [Flood-based Agriculture], Extensification (land use or land cover transformation, ecological practice, or conversions), Water and soil protection (rotating, intercropping, catch crop, mulch, green manure);

GOV: Official frameworks (building code, guidelines, directives, laws, legislative instruments, plans, projects, programs), Cooperative society (participation, communication, organisation, goninggumi, family \& friends, microfincancing, rituals) or [Societal Cooperation], Emergency preparation (rescue, flood emergency reservoir), Evacuation system (location of evacuation areas and evacuation routes), Compensation system (state or index-based insurance, flood-prone ID), Analysis of management practices ** (failures and successes), Inclusion of knowledge (also indigenous, local, ecological) \& provision of education (i.e., marks) or [Knowledge Transfer Systems], Media and telecommunication (TV, radio, internet, phones) or

[Tele-Media-Communications], Warning system (yells, movements, instruments, EFAS, GloFAS, GFDS, WeSenseIT), Hydro-geo-information

(mapping, forecasting, database, remote sensing, modelling, future risk analysis)

General Flood Mitigation Effect

Spatial Setting
Positive, Potentially positive, Negative

Urban, Rural, Lowland, Mountain, RuralLowland, RuralLowlandMountain, RuralMountain, UrbanLowland, UrbanRural, UrbanMountain, UrbanRuralLowland, UrbanRuralMountain, UrbanRuralLowlandMountain, Missing

Local [ $<100 \mathrm{~km}]$, Regional [100 km to $250 \mathrm{~km}$ ], and Supraregional [>250 km], LocalRegional, RegionalSupraregional, LocalRegionalSupraregional, Missing

Increasing, Directly Reducing, Indirectly Reducing, Increasing to Directly Reducing ${ }^{4}$, Missing

\begin{tabular}{cc}
\hline Technical Feasibility & Easy, Complex, EasyComplex ${ }^{5}$, Missing \\
\hline Environmental Effect & Friendly, Damaging, FriendlyDamaging ${ }^{6}$, Missing \\
\hline Economic Effect & Cost-effective, Costly, CheapCostly ${ }^{7}$, Missing \\
\hline
\end{tabular}


Table 1. Cont.

\begin{tabular}{cc}
\hline List of Variables & Modalities \\
\hline Societal Effect & Enhancing, Weakening, Missing \\
\hline Flood Severity ${ }^{8}$ & $\begin{array}{c}\text { HQ10, HQ50, HQ100, overHQ100, HQ100overHQ100, HQ10HQ50, } \\
\text { HQ10HQ50HQ100, HQ10HQ50HQ100overHQ100, HQ50HQ100, Missing }\end{array}$ \\
\hline Effect on Peak Discharge & Delaying, Reducing, DelayingReducing, Missing \\
\hline Delay of Peak Discharge & $13 \mathrm{~min}, 15 \mathrm{~min}, 30 \mathrm{~min}, 180$ min, 2400 min, $4800 \mathrm{~min}$, Missing \\
\hline Reduction of Peak Discharge & $0 \%$ 24\%, 25\%_49\%, 50\%_74\%, 75\%_100\%, over100\%, Missing \\
\hline
\end{tabular}

${ }^{1}$ following [74,75]. ${ }^{2}$ following [7,76]. ${ }^{3}$ following [26,77]. ${ }^{4}$ e.g., [20]. ${ }^{5}$ e.g., [78]. ${ }^{6}$ e.g., [ 45,69$] .{ }^{7}$ e.g., [52]. ${ }^{8}$ recurrence probability HQ in years following $[21,64,79] . *$ Meaning global analyses such as reviews. ${ }^{* *}$ Only found as mentioned in literature for FM in non-European rural mountainous areas.

\subsubsection{Pre-Proceeding}

We extracted a total of 442 records about measures published in 152 references and analyzed them using Multiple Correspondence Analysis (MCA) in RStudio (RStudio Team 2020, v 1.3.1073) with R (v4.0.3, 2020-10-10). MCA is an extension of Correspondence Analysis, which analyzes more than two categorical variables [80]. The analysis is generally used to reveal so-called typologies [81] or patterns in a data set for modalities with the same and a significant orientation in the considered dimensions [80]. Variables of the data set defined as "active" are used to perform the mathematical calculation, which can then be interpreted by records (individuals) and modalities (categories of active variables), as well as described by supporting variables ("supplementary") and their categories [80]. We combined variables which were separate in the initial characterization of sources ("rural" and "mountain") to new ones ("spatial setting") (Table 1) to gain a more meaningful MCA [80]. To further increase the efficiency of the calculation and the graphical interpretation of the MCA, an equal number of modalities per variable across the data set was aimed for [82], e.g., through grouping (e.g., "period of year", "continents [subregions]", "reduction of peak discharge" in Table 1). The statistics-based literature analysis was performed on three sub-data sets (SDS): (SDS-1) measures in ERMA (92 records from 25 references), (SDS-2) measures in non-European rural mountainous area (NERMA) (74 records from 17 references), and (SDS-3) measures in other mountainous areas (OMA) (276 records from 64 reference). SDS-3 included, e.g., measures implemented in more urbanized and lowland mountainous areas and excluded records already used in SDS- 1 and SDS-2.

\subsubsection{Analysis of the Measures and Flood Management Extracted from the Literature}

Previous research underlined the use of MCA on data extracted from literature by text mining approach [83-87], as well as the stratification of the created data set [88-90]. In contrast, subset MCA would be proposed in case of analyzing only a set of categories or variables [91,92].

MCA was performed on the SDS using R package soc.ca (v0.7.3) [93]. The percentages of missing data points varied within variables and SDS, which led to deviating combinations of active and supplementary variables for the built models. Variables such as "authors", "country" and "region", "measures", and "measure keywords" were defined as supplementary variables and excluded from calculations due to their disproportional number of modalities. All other variables were initially assumed to be active variables and included in calculations. The model most efficiently explaining every SDS was built by successively declaring variables with higher and more unbalanced number of categories as well as higher percentage of data gaps as "supplementary" in descending order. We aimed for the smallest possible number of dimensions with the highest possible homogeneity in the explanatory contributions of the active variables explaining at least $80 \%$ of data set variability. Missing data points could be handled in soc.ca-package by excluding them from calculation through a label ("Missing") turning the analysis into a specific MCA. This gives the advantage of preserving and including the available information of lacky 
records to the MCA. In that way, we increased the information gain and power of the analysis [91]. Even though imputation of data gaps exists [94], it requires at best only $10 \%$ or less of the data to be missing $[95,96]$, which was not the case, otherwise the quality of imputation decreases [97]. We mainly used the Euclidean positional distance ED (next to contribution, and correlation coefficient) to assess the MCA output. A modality with an ED vector amount above 0.5 [80] and between 0.40 and 0.49 was considered significant.

The prioritization of FM phases was assessed by 63 sources and the FM characteristics by 89 sources (Table A1) following the same process of data collection described in Section 2.1.1. Information was extracted by reading when mentioned in the text following the terminology displayed in Table 2, counting an FM phase or FM characteristic only once per source, considering similar keywords and terms. Finally, 15 phases and 34 characteristics were assessed in the literature analysis (Table 2). A simple comparison of counts for FM phases and for FM characteristics was conducted in a ranking scheme to assess their value in FM, defining more counts as more important.

Table 2. Modalities used for the assessment on prioritized FM phases inspired by [43] (\# plus a number indicating its position in FM cycle) and assessed FM characteristics in the expert survey and analyzed literature. "Phases" were the same in both analyses while the literature analysis assessed "characteristics" and "additional characteristics" and, in the survey only, "characteristics".

\section{Phases}

Natural water retention (e.g., Sponge vegetation) (\#1);

Technical flood defense (e.g., Levee) (\#2);

Land use regulation (e.g., Zoning) (\#3);

Building codes (e.g., Flood-prone ID) (\#4);

Building retrofitting (e.g., Water shutter) (5); Insurance (e.g., Refunding) (\#6);

Training or exercises (e.g., Workshop) (\#7);

Early warning systems (e.g., EFAS) (\#8);

Emergency measures (e.g., Evacuation, sandbag wall) (\#9);

Relief (e.g., First aid, food, clothes) (\#10);

Rehabilitation (e.g., Clean up, viable infrastructure) (\#11);

Reconstruction (e.g., Damaged levees) (\#12);

Event documentation (e.g., Marks, resource demand) (\#13);

Data analysis, modeling and mapping (e.g., Flood risk maps) (\#14);

Risk assessment and evaluation of measures (e.g., Failures and successes) (\#15);

\section{Characteristics}

Additional Characteristics

Ecosystematic integral or
Ecologically integrated
(socio-ecological);
Cost-effective;
Social, accepted,

communicative, participative, collective;

(eco) Sustainable, long-term;

Complementary/not

enough/combination/mixture;

Holistic/monitoring;

Multifunctional;

Strategic, smart, systematic, organized;

Resilient;

Decentralized/autonomous; Adaptive;

Flexible, agile;

Heterogenic/diverse;

Transformable;

Modular;

Robust;

Redundant;

Climate fair;

Feasible

\subsection{Survey}

\subsubsection{Interviewee Selection}

An expert-based survey was conducted according to type 3 delphi process [98]. To recruit potential interviewees, two approaches were chosen to create a pool of experts (Table 3). In total, 197 experts were invited to participate in the survey. 
Table 3. List of pools used to identify interviewees for the expert survey. ${ }^{*}$ Projects before 1999 lacked contact information and seemed outdated.

\begin{tabular}{|c|c|c|c|c|}
\hline $\begin{array}{c}\text { Sources for } \\
\text { Interviewee Pool }\end{array}$ & $\begin{array}{l}\text { Number of } \\
\text { Interviewees }\end{array}$ & Link to Project Data Bases & Filters & Notes \\
\hline Google Search & 121 & Google.com & $\begin{array}{l}\text { "flood" "research" } \\
\text { "university" }\end{array}$ & 16 November 2020 \\
\hline World Bank & 20 & $\begin{array}{l}\text { projects.worldbank.org/en/ } \\
\text { projects-operations/ }\end{array}$ & $\begin{array}{l}\text { "flood" Europe } \\
\text { after } 1999 *\end{array}$ & $\begin{array}{c}24 \text { projects, some } \\
\text { shared the same leader }\end{array}$ \\
\hline EU-LIFE & 27 & $\begin{array}{l}\text { ec.europa.eu/environment/ } \\
\text { life/project/Projects/ }\end{array}$ & flood & \\
\hline RECONNECT & 7 & - & - & \\
\hline PHUSICOS & 22 & - & - & \\
\hline
\end{tabular}

\subsubsection{Survey Form}

The online platform SosciSurvey (soscisurvey.de, SoSci Survey GmbH, Munich, DE) was used to create and conduct the survey (Supplementary Material S1). The survey ran between 21 December 2020 and 25 February 2021. After a brief description of the project and the survey procedure, as well as conditional consent to participation (anonymous), socio-professional information of the participant was first requested. The answer options or even complete questions of the survey could be omitted and skipped in the later sections of the survey. The questions regarding FM consisted of the following: (1) Which aspect(s) (flood reduction, technology, environment, economy, society) can be covered by a flood management measure?; (2) Which of the following measures in flood management could be applied in rural mountain areas across Europe $(1=$ rarely applicable to 5 = totally applicable)?; (3) What is the spatial impact or effect of a measure (local: $<100 \mathrm{~km}$, regional: $100 \mathrm{~km}$ to $250 \mathrm{~km}$, supraregional: $>250 \mathrm{~km}$ )?; (4) How important are certain flood management aspects like prevention, protection, reaction, and lessons learnt to you (1 = important to 15 = unimportant)?; and (5) What should (future) flood management look like (e.g., decentralized or holistic) $(1=$ important to $19=$ unimportant)? Alternatively, optional answers could be given, checking lack of experience ("limited experience"), insufficient information ("more information"), or none of the options provided ("none"). Questions 1 and 3 were asked with multiple response options. Questions 2, 4, and 5 were designed as simple analysis of variance by ranks and blocks with repeated measures. The prioritization of FM phases and characteristics was assessed by the terminology and from the sources in Tables 2 and A1, while only 19 of 34 characteristics used in the literature analysis were given to keep the task simple (Table 2). Sources and terminology were generated as described in the Section 2.1.1.

\subsubsection{Survey Data Pre-Proceeding Process}

Survey data were downloaded from SosciSurvey at the end of the survey period and analyzed in RStudio. Only questionnaires with at least one of five questions answered were considered in the analysis. Answers completely missing for a question were removed for the respective analysis. Individual missing data points were replaced with the median of the corresponding category answer. Average response rate accounted for $18.8 \%$ records available from analysis (37 experts), however, sample sizes varied for each question due to incomplete parts by some interviewees.

\subsubsection{Analysis of Survey Data}

Descriptive and exploratory factorial statistical methods were applied to the socioprofessional information and Question 1 and 3. Questions 2, 4, and 5 were subjected to a two-sided Friedman test (R-package PMCMRplus v1.7.1), followed by a Friedman Conover test (post-hoc test) (R-package PMCMR v4.3). The respective test functions friedmanTest() 
and posthoc.friedman.conover.test() were used and set to $\mathrm{y}=$ ratings, groups $=$ measure categories, blocks $=$ people rating, p.adjust.method $=$ "BY". The reliability or agreement of and among expert ratings was assessed by Kendall's coefficient of concordance (Kendall Wt in R package DescTools v0.99.39 with <data, correct $=$ TRUE, test $=\mathrm{T}>$ ), the likert() function (R-package likert v1.3.5) and the consensus() function (R-package agrmt v1.42.4) $[99,100]$. The results of the post-hoc tests were visualized by a compact letter display for calculated medians with confidence interval by group [101].

\section{Results}

The results of the systematic literature review are ordered according to the SDS and contain in the first part a general description of SDS and MCA and, in a second part, a detailed comparison of similarities and dissimilarities among SDS results. The second half of this section covers the expert survey and finishes with a comparison of literature and survey.

\subsection{Analysis of Literature}

The MCA part considers the first three dimensions since they explained more than $80 \%$ of the data variability (Table 4) based on the final configurations (Table A2, Figures A1-A3). In all SDS, little reporting was available on the variables "spatial effect range", effects in economy, technology, ecology, and society and influences on peak discharge $(<10 \%$ to $30 \%$ of the cases), which were then configured as supplementary in MCA calculations. Despite the unexpectedly rich knowledge in the literature about FM in mountainous areas, only $21 \%$ of the publications found related to FM in ERMAs (Table 4).

Table 4. Overview of sub-data set (SDS) information $(\mathrm{N}=442)$ used in MCA.

\begin{tabular}{|c|c|c|c|}
\hline Variables & SDS-1 & SDS-2 & SDS-3 \\
\hline Proportion of publication & $21 \%$ & $17 \%$ & $62 \%$ \\
\hline First publication found & 2005 & 2007 & 1981 \\
\hline Publication hotspot & 2006-2008, 2011/12, 2016/17 & $2007,2016,2018 / 19$ & $\begin{array}{c}1995,2007 / 09,2015-2017, \\
2019 / 20\end{array}$ \\
\hline Geographical focus & Central Europe & Asia & $\begin{array}{l}\text { Global (Europe, } \\
\text { America, Asia) }\end{array}$ \\
\hline $\begin{array}{l}\text { Proportion of studied } \\
\text { natural measures }\end{array}$ & $39 \%$ & $20 \%$ & $25 \%$ \\
\hline $\begin{array}{l}\text { Proportion of studied } \\
\text { engineered measures }\end{array}$ & $23 \%$ & $15 \%$ & $25 \%$ \\
\hline $\begin{array}{l}\text { Proportion of studied } \\
\text { instrumental measures }\end{array}$ & $38 \%$ & $65 \%$ & $50 \%$ \\
\hline $\begin{array}{l}\text { Explained data variability by } \\
\text { the first three dimensions }\end{array}$ & $85.5 \%$ & $93.2 \%$ & $90.9 \%$ \\
\hline
\end{tabular}

In SDS-1, natural solutions are the most studied (39\%), while in SDS-2 and SDS-3, more instrumental solutions were reported on ( $65 \%$ and $50 \%$, respectively) (Table 4). Interestingly, in ERMAs, NBS were found to be associated with addressing multiple flood severities and a higher peak reducing function than engineered solutions (Table 5). However, generally, only few details on the multifunctionality of measures were found for ERMAs (Table 5). In addition, no publications on ERMAs were found to deal with warning systems, emergency preparation, nature conservation, flood-based agriculture, managed retreat, mobile embankment, tele-media-communication, and watershed restoration (Figure 3). 
Table 5. Synthesis of the assessment of the solutions (* European rural mountainous areas, \# non-European rural mountainous areas, + other mountainous areas). Instrumental solutions gathered: governance, urban and rural planning, and land use and land management solutions.

\begin{tabular}{|c|c|c|c|}
\hline Variables & Engineered Solutions & Natural Solutions & Instrumental Solutions \\
\hline General Effect & Negative * & Potentially positive + & Potentially positive \# \\
\hline Spatial Effect Range & $\begin{array}{c}\text { Local + } \\
\text { Regional + }\end{array}$ & $\begin{array}{c}\text { Local * + } \\
\text { Regional * + }\end{array}$ & $\begin{array}{c}\text { Local \# + } \\
\text { Regional \# } \\
\text { Supraregional \# + }\end{array}$ \\
\hline Effect on Flooding & $\begin{array}{l}\text { Directly reducing \# + } \\
\text { Directly Increasing + }\end{array}$ & Directly reducing + & Indirectly reducing \# + \\
\hline Technical Feasibility & $\begin{array}{c}\text { Easy \# } \\
\text { Complex * }\end{array}$ & $\begin{array}{c}\text { Easy* } \\
\text { Complex* }\end{array}$ & not significant \\
\hline Environmental Effect & $\begin{array}{l}\text { Damaging * + } \\
\text { Friendly \# + }\end{array}$ & $\begin{array}{l}\text { Friendly* \# + } \\
\text { Damaging \# + }\end{array}$ & not significant \\
\hline Economic Effect & $\begin{array}{l}\text { Costly + } \\
\text { Cheap \# }\end{array}$ & $\begin{array}{l}\text { Costly + } \\
\text { Cheap * }\end{array}$ & Costly* \\
\hline Societal Effect & Enhancing *\# & & Enhancing + \\
\hline Flood Severity & HQ50 + & $\begin{array}{l}\text { HQ10*+ } \\
\text { HQ50*+ } \\
\text { HQ100*+ }\end{array}$ & $\begin{array}{c}\text { HQ10* } \\
\text { HQ50 * } \\
\text { HQ100* + }\end{array}$ \\
\hline Effect on Peak Discharge & $\begin{array}{l}\text { Delaying \# + } \\
\text { Reducing * + }\end{array}$ & $\begin{array}{l}\text { Delaying *\#+ } \\
\text { Reducing *\# + }\end{array}$ & not significant \\
\hline Delay of peak discharge & $\begin{array}{c}15 \min + \\
30 \min + \\
180 \min + \\
4800 \min +\end{array}$ & $\begin{array}{c}15 \min ^{*}+ \\
30 \min + \\
180 \min + \\
4800 \min +\end{array}$ & not significant \\
\hline Reduction of Peak Discharge & $\begin{array}{l}-0 \% \text { to }-49 \%{ }^{*}+ \\
-50 \% \text { to }-74 \%{ }^{*}+ \\
>100 \%+\end{array}$ & $\begin{array}{c}-0 \% \text { to }-74 \%+ \\
-25 \% \text { to }-49 \% \# \\
-75 \% \text { to }-100 \% *+ \\
>100 \%+\end{array}$ & not significant \\
\hline
\end{tabular}

The MCA of SDS-2 showed that not only NBS but also engineered solutions could exhibit positive functional effects and a broad spectrum of effects compared to the information for engineered solutions within SDS-1 (Table 5). Interestingly, while NBS were assessed as effective on flood protection, they were assessed as conducive to damaging the environment (Table 5), either through increased water-soil-infiltration and surface roughness by vegetation cover [102] or worsened drought through changing it from deciduous to coppice stands [69], respectively. No publications in NERMAs were found to report on managed retreat, mobile embankment, river restoration, soft floodwater retention, tele-media-communication, and watershed restoration (Figure 3). Interestingly, instrumental solutions were a research focus mostly in urbanized areas. In OMA, the functions of engineered and natural solutions remain rather unclear because of a broad range of effects (Table 5). 


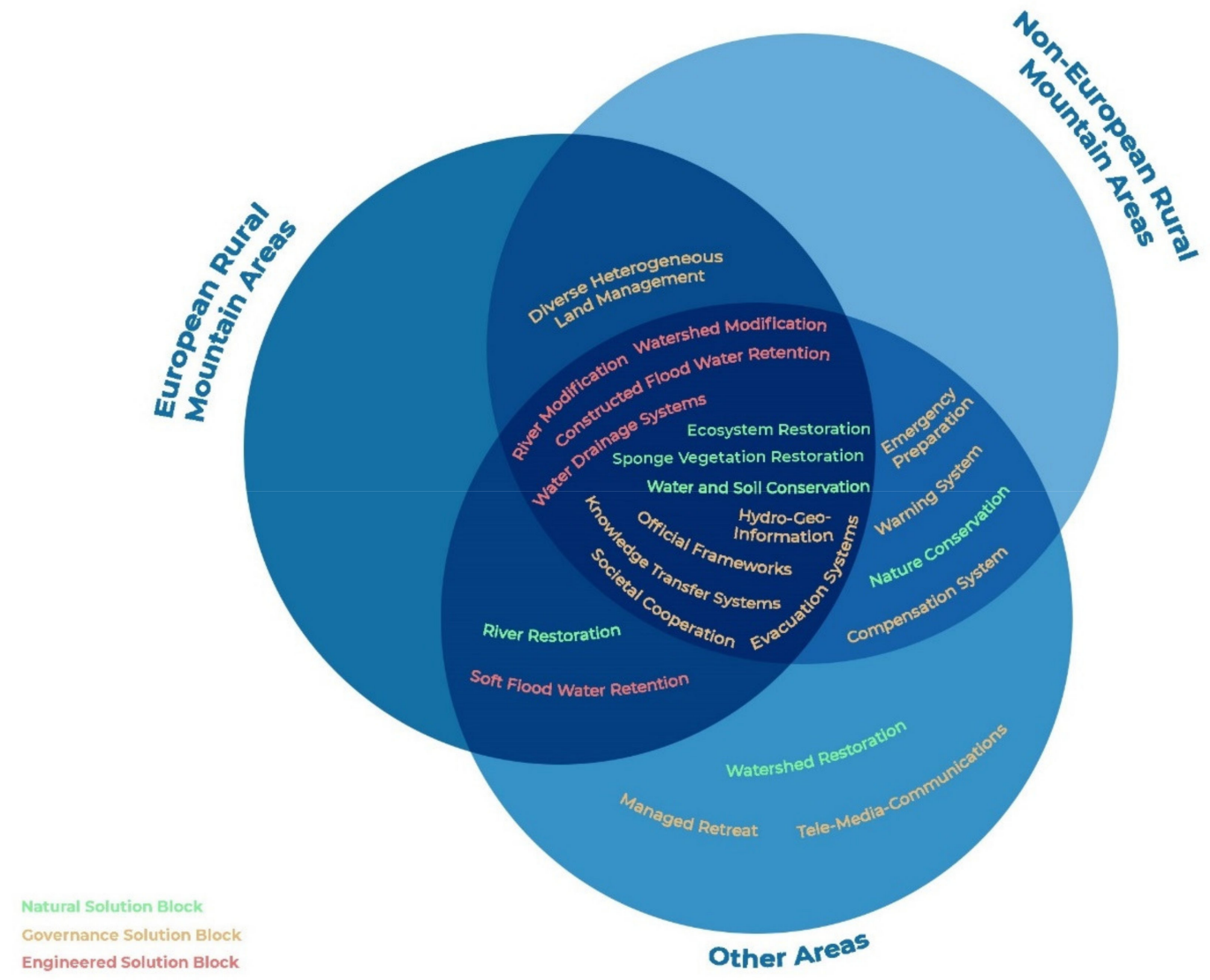

Figure 3. Distribution of the FM measures (FMM) presented in each sub-data set.

3.1.1. Combination and Comparison of Dissimilarities and Similarities between the Distinguished Geographical Areas (Sub-Data Sets)

Combining all the found knowledge in literature, it was possible to obtain a broad assessment of the solutions, however, disparities existed (Table 5). First, the overall picture resulting from the combination of the data showed that engineered solutions had an overall negative effect. They were efficient for delaying and reducing the peak discharge of medium floods but inefficient with large floods such as HQ100 and greater, causing more direct increases in the flood risk. The spatial effect of the measures was mostly local and regional. Second, considering the natural solutions, data showed an overall positive assessment of the measures. They showed a great efficiency for small to large floods, acting directly to reduce the hazards (reduction and delay of the peak discharge). No significant association to risk increase and large-scale effect by NBS was found. The spatial effect of measures was significant on a local to regional scale. The feasibility and costs varied. Instrumental solutions showed indirect flood risk reduction and a local to supraregional scale of effect. They were efficient for all types of flood severity but costly.

Comparing the knowledge between the sub-data sets showed disparities. First, natural solutions in ERMAs were assessed as environmentally friendly and cheap, while NERMA studies and OMA studies were more skeptical when considering the effect on the environment. Furthermore, while NBS were assessed as cost-efficient in ERMAs and NERMAs, they were assessed as costly in OMAs. The efficiency of the measures, namely delay and reduction of peak discharge, were identified in all distinguished geographical areas. However, peak discharge reduction was the most variable in OMAs $(0 \%$ to over $100 \%$ ), followed by ERMAs (74\% to $100 \%$ ), and then NERMAs (25\% to $49 \%$ ). Delays in peak discharge were short in ERMAs $(15 \mathrm{~min})$ and from short up to very long in OMAs (15 to $4800 \mathrm{~min}$ ). Second, engineered solutions were negatively assessed in ERMAs and positively assessed in NERMAs. In OMAs, the assessment was heterogeneous, especially 
when considering environmental friendliness and effects on the hazard. In all areas studied, engineered solutions were assessed as effectively reducing medium flood events with some negative consequences, such as being cost-intensive, environmentally damaging, or even increase in hazard. In NERMAs, engineered solutions showing characteristics such as NBS had positive connotations. Third, instrumental solutions showed the fewest significant associations of modalities in all geographical areas but assigned a local to supraregional scale of flood mitigation and indirect flood risk reduction for NERMAs and OMAs. Studies in ERMAs gave considerable associations between non-structural solutions and flood severities between HQ10 to HQ100.

\subsubsection{Phase Prioritization of (Flood) Disaster Management}

Few differences were seen in the relevance of FM phases comparing the mention in the reviewed literature to the reading order (clockwise) of the established flood risk management circle. Changes occurred in the back and front midfield (Figure 1 vs. Figure 4). Immediate post-event phases were less studied (3-8\%), and early pre-event phases were studied extensively (33-50\%), "natural water retention" being most often mentioned in the reviewed literature (Figure 4). It is worth noting that intermediate pre-event phases (e.g., training or exercises) and late post-event phases (e.g., risk assessment and evaluation of measures) received $12.7 \%$ to $22.2 \%$ of the attention in the literature studied. It was found that intermediate pre-event and late post-event phases appeared far more often in the reviewed literature than their place in the flood risk management cycle would suggest. However, other intermediate pre-event phases, e.g., building codes, were mentioned less often than it would be expected from the flood risk management cycle.

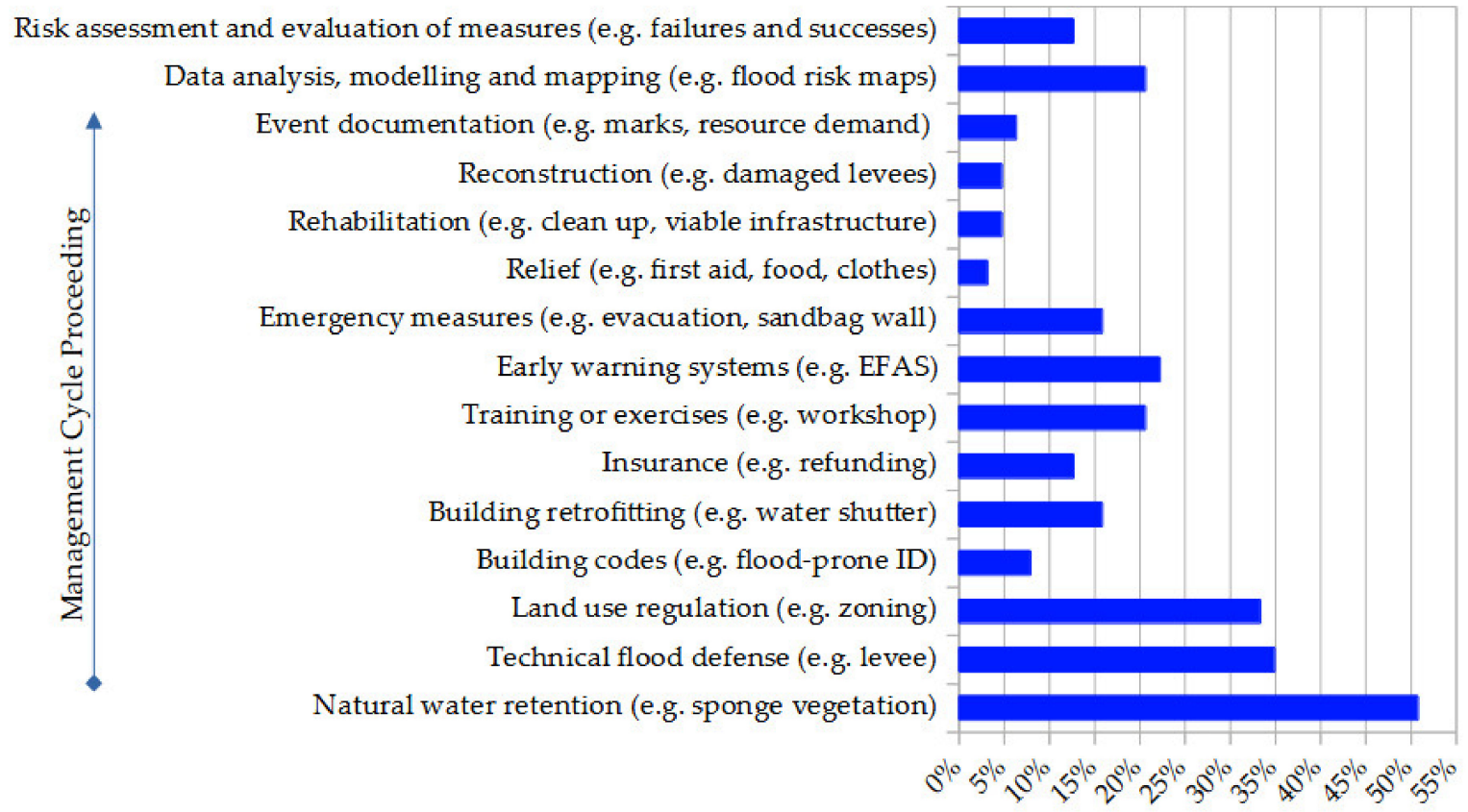

Percentage of findings in the reviewed literature

Figure 4. Percentage of literature referring to phases in the FM cycle $(\mathrm{N}=63)$.

\subsubsection{Important Characteristics for Flood Management}

The characteristics described for FM in the reviewed literature included primarily ecological and socially acceptable aspects, as well as a combination of FM, maintenance, and decentralization (Figure 5). Other similar characteristics, such as "modular", "climate-fair", or "robust", were found less frequently. 


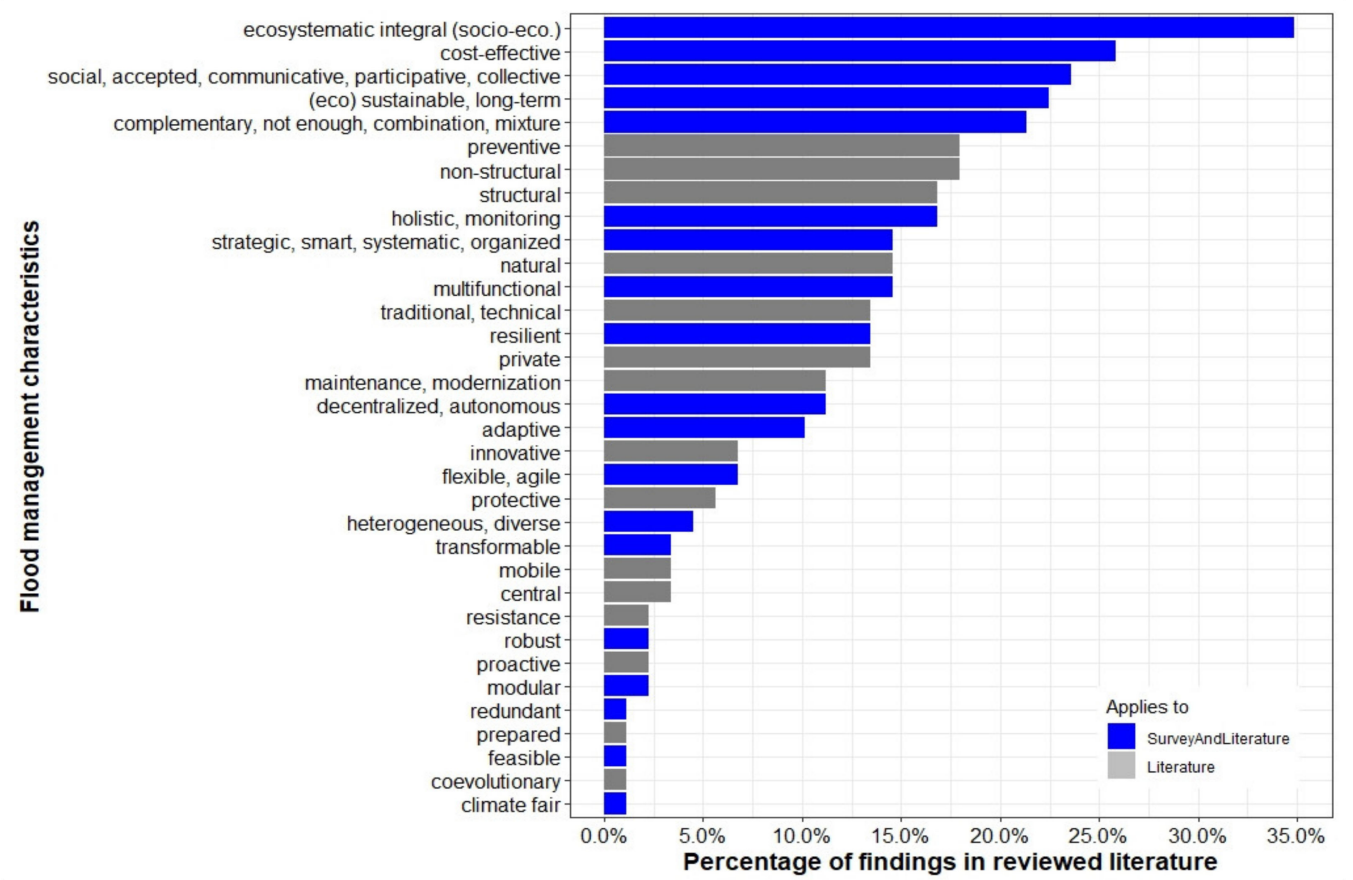

Figure 5. Percentages of characteristics important for FM $(\mathrm{N}=89)$. Characteristics considered in the survey are with blue bars, and both blue and grey were considered in the literature analysis.

\subsection{Analysis of Expert Survey}

After a detailed examination of the socio-professional information, it was found that the experts showed 1 to 55 years of experience in the field ( $12 \pm 11.86$ years, median \pm MAD) and worked in the European region and especially in the ERMA. For these reasons, their statements made in the survey were considered as legitimate for the purpose of the study. Details and information about the distribution of Likert scores (Figures A4-A6) and consensus values (Figures A7-A9) among experts can be found in Appendices $C$ and D, respectively.

\subsubsection{Multifunctionality of Flood Mitigation Measures}

The evaluation of functions of the measures highly varied between the experts (Figure 6). Seventeen people were not able to assess the functions of measures. At least one function was assigned to all measures (Figure 6), with "not available", "limited experience", or "flood reduction" being under the top 20 mentions in applying functionalities assigned by experts. "Emergency preparation" was the most cited measure for economic and societal benefits (ten mentions), closely followed by "river restoration" (without easy technical implementation) and "constructed flood water retention", with nine mentions on economic and societal benefits, and by "water retention slowdowns and drainage systems" with nine mentions for flood reduction function, the latter being the single functionality mentioned most often (37 times). The combination of the flood-reducing, environmentally friendly, and economically beneficial, as well as the socially beneficial functionalities of a measure was mentioned 21 times, as well as the combination of flood-reducing and economically and socially beneficial. 


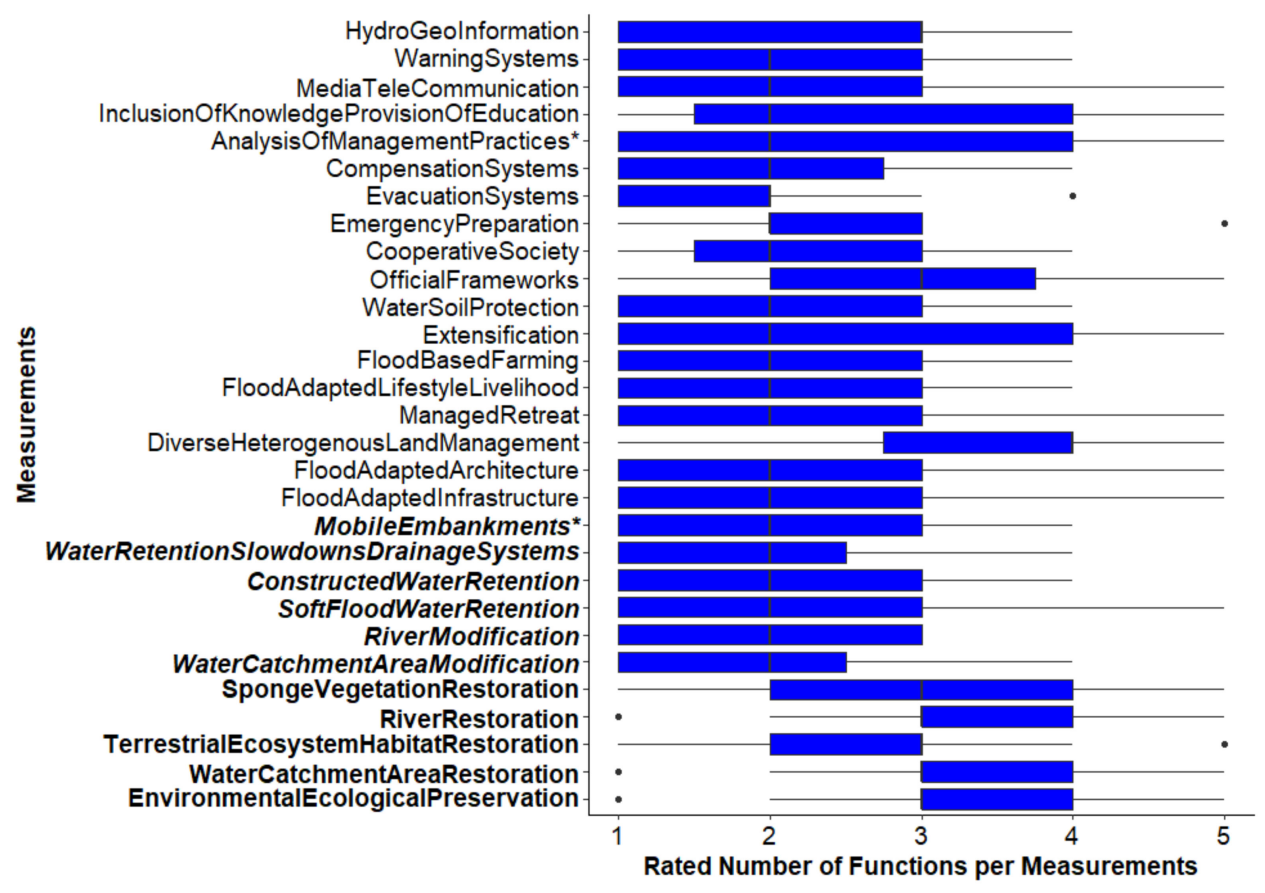

Figure 6. Rated multifunctionality of measures by experts $(\mathrm{N}=33)$. Multiple choice was possible. * Only represented in sub-data set 2 (SDS-2) about FM in non-European rural mountain areas. Instrumental (plain), structural (bolditalic), and natural solutions (bold).

3.2.2. Applicability of the Measures for European Rural Mountainous Regions

Around two-thirds of the measures (20 of 29) were assessed as moderately to highly applicable to ERMA, especially high for NBS (Figure 7).

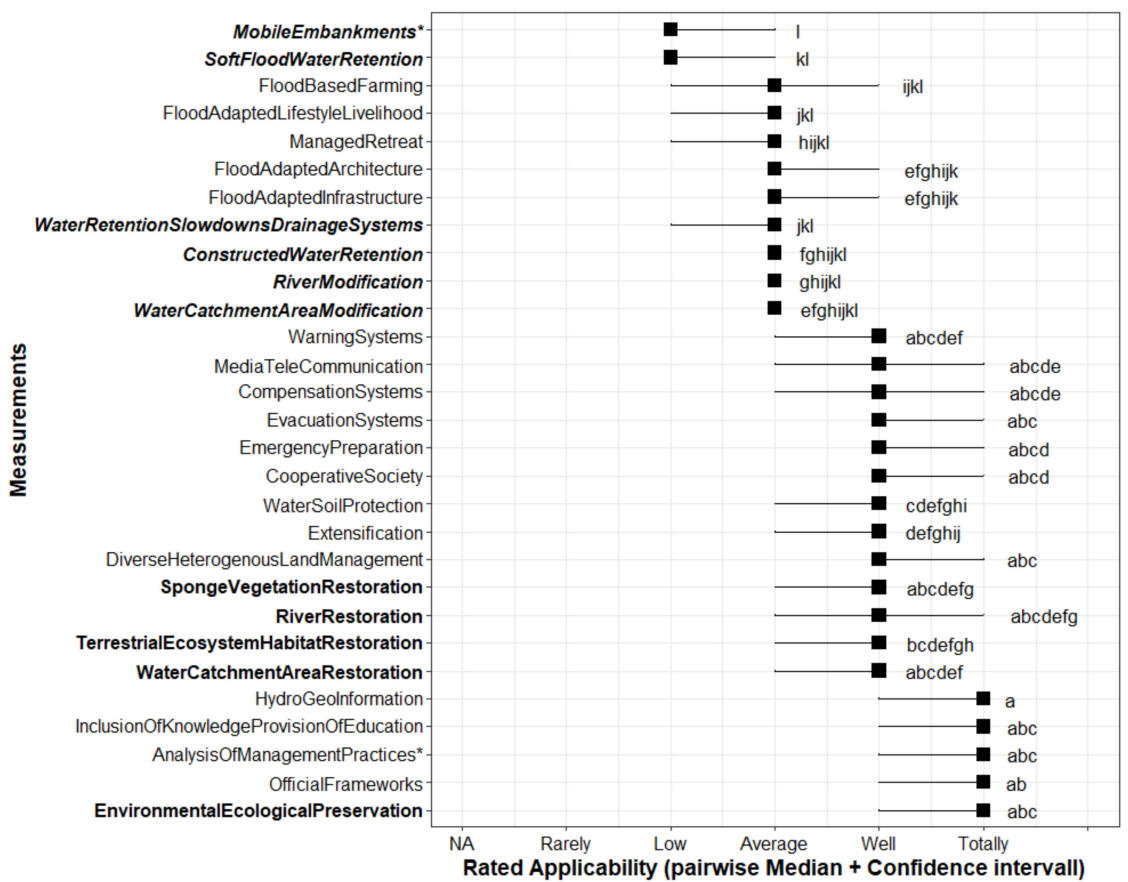

Figure 7. Statistical differentiation by the Friedman Conover test of measures regarding their applicability in European rural mountain areas (Friedman $\chi_{\mathrm{fm}}$ and Kendall Wt test-statistics: $p<2.2 \times 10^{-16}$, $\left.\mathrm{df}=28, \chi_{\mathrm{fm}}=231.37, \mathrm{Wt}=0.285\right)$. Ratings of measures sharing a letter (e.g., "a" in OfficialFrameworks and RiverRestoration) could not be statistically differentiated. * Only represented in SDS-2. Instrumental (plain), structural (bolditalic), and natural solutions (bold). 
The remaining third rated with low to moderate applicability is composed of many instrumental and engineered solutions (Figure 7). Only a few measures were given low or very good applicability for ERMAs, e.g., "mobile embankments" or "hydro-geo information", respectively (Figure 7). It is worth noting that measures missing in SDS-1 but available in SDS-2 (NERMA) and described as effective there (i.e., nature conservation, compensation systems, and warning systems) were assessed as highly to very highly applicable in ERMAs (Figure 7). Furthermore, for about half of the measures, it could be said that those with higher applicability in ERMAs provided also more than one functionality (Figures 6 and 7).

\subsubsection{Spatial Impact of the Flood Mitigation Measures}

The assessment revealed that the spatial range was heterogeneous, so that either no clear spatial effect or only one spatial extreme (local or supraregional) was indicated by the experts (Figure 8). Deviations were shown by "flood-adapted architecture", "hydro-geo information", and "river modifications", which showed local and supraregional ranges (Figure 8). A few measures were found to have almost exclusively $50 \%$ local effects, while the vast majority were found to have $50 \%$ regional effects and occasionally supraregional effects. All measures received at least one or more mentions of limited experience from the experts.

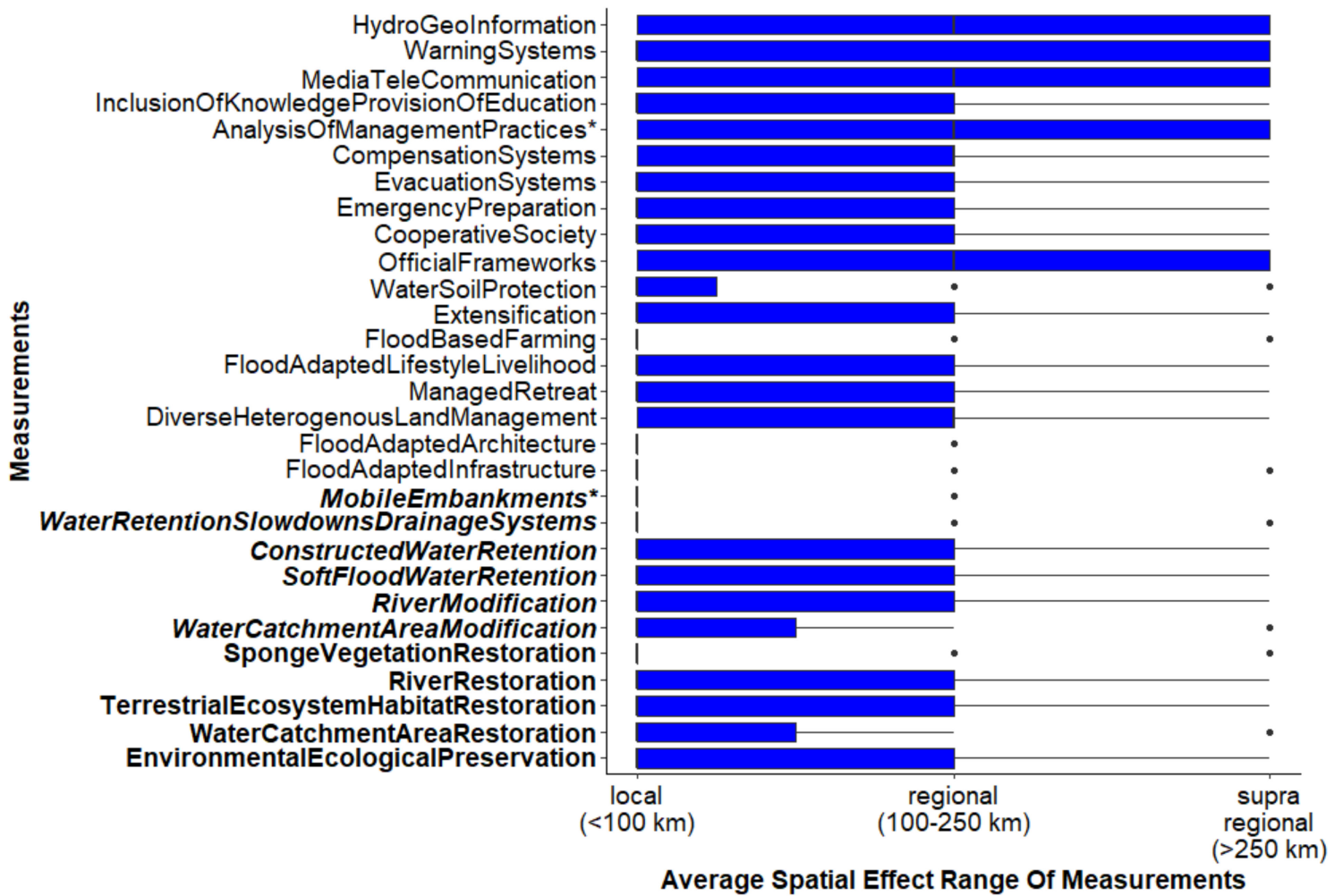

Figure 8. Average effective spatial range of FMM $(\mathrm{N}=29)$. Multiple choice was possible. * Only represented in SDS-2. Instrumental measures (plain), structural measures (bolditalic), and natural measures (bold).

\subsubsection{Prioritization of Flood Management Phases by the Experts}

The most common medians ranked around 10 or 11 (less important), such as for insurance or rehabilitation, and 5 (more important), as for natural water retention (Figure 9). The experts showed less consensus in ranking the priority of FM phases compared to rating the applicability of measures (Figure A7 vs. Figure A8). Phases of prevention and precaution (including natural water retention, technical flood defense, land use regulation, and building regulations) were rated most important for FM (Figure 9). The applicability in ERMA of measures belonging to these phases was rated as feasible (Figures 7 and 9). 


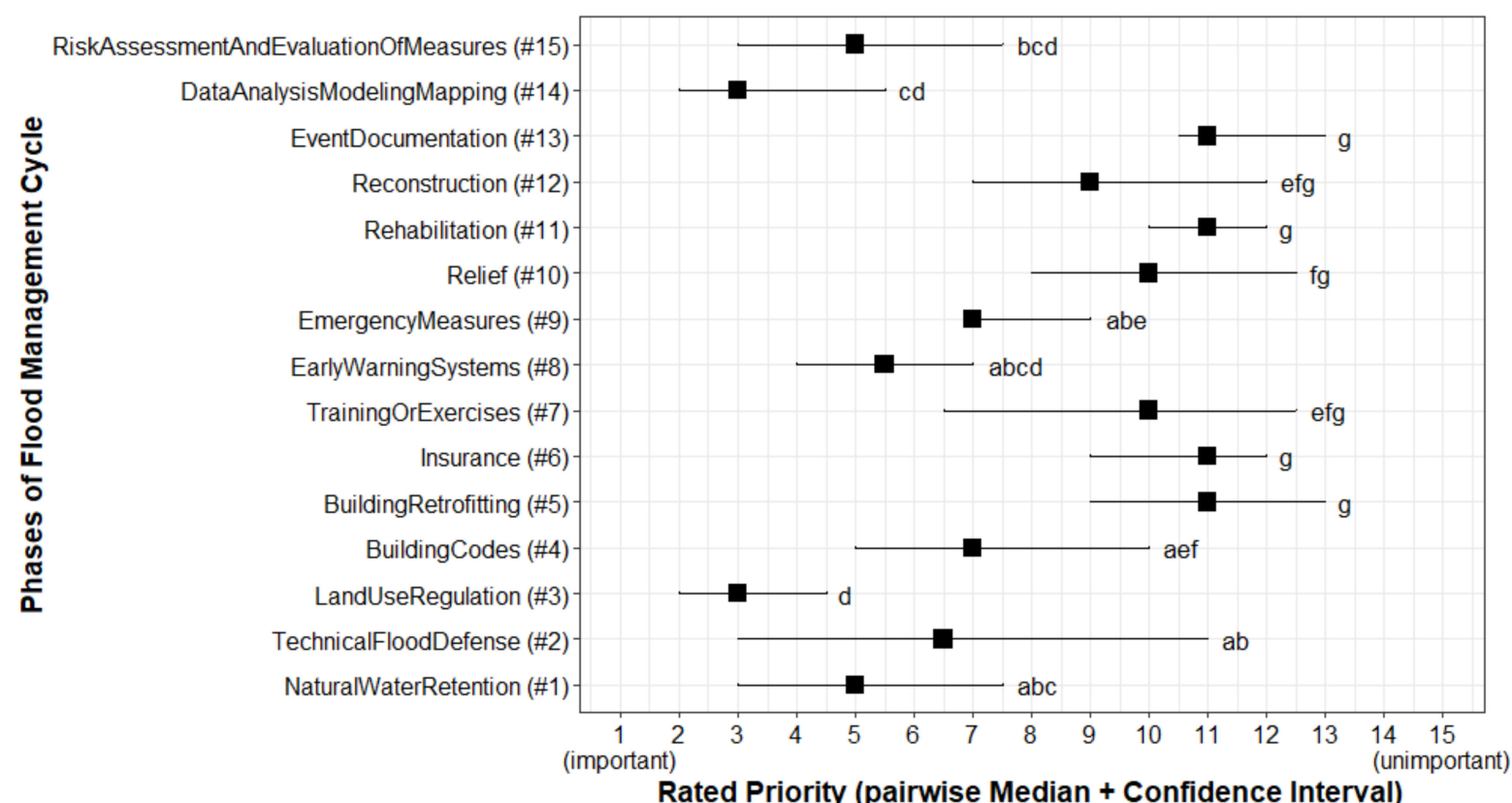

Figure 9. Statistical differentiation by the Friedman-Conover Post hoc test of phases in FM cycle regarding their importance (Friedman $\chi_{\mathrm{fm}}$ and Kendall Wt test-statistics: $p<2.2 \times 10^{-16}, \mathrm{df}=14, \chi_{\mathrm{fm}}=108.22, \mathrm{Wt}=0.276$ ). Ratings of phases sharing a letter (e.g., "a" in EmergencyMeasures and NaturalWaterRetention) could not be statistically differentiated. The \# followed by a number refers to their position in the FM cycle (see Sections 1 and 3.1.2).

\subsubsection{Important Characteristic for Flood Management}

The agreement within the group of experts showed a relatively strong polarity for the presented characteristics with only few assigned to middle ranks (Figure 10 and Appendices C and D). A plateau occurred at ranks 6 until 11, between "climate-fair" and "strategic/smart" (Figure 10). The most unimportant rated characteristic was "redundant" and the most important "sustainable, long-term" (Figure 10).

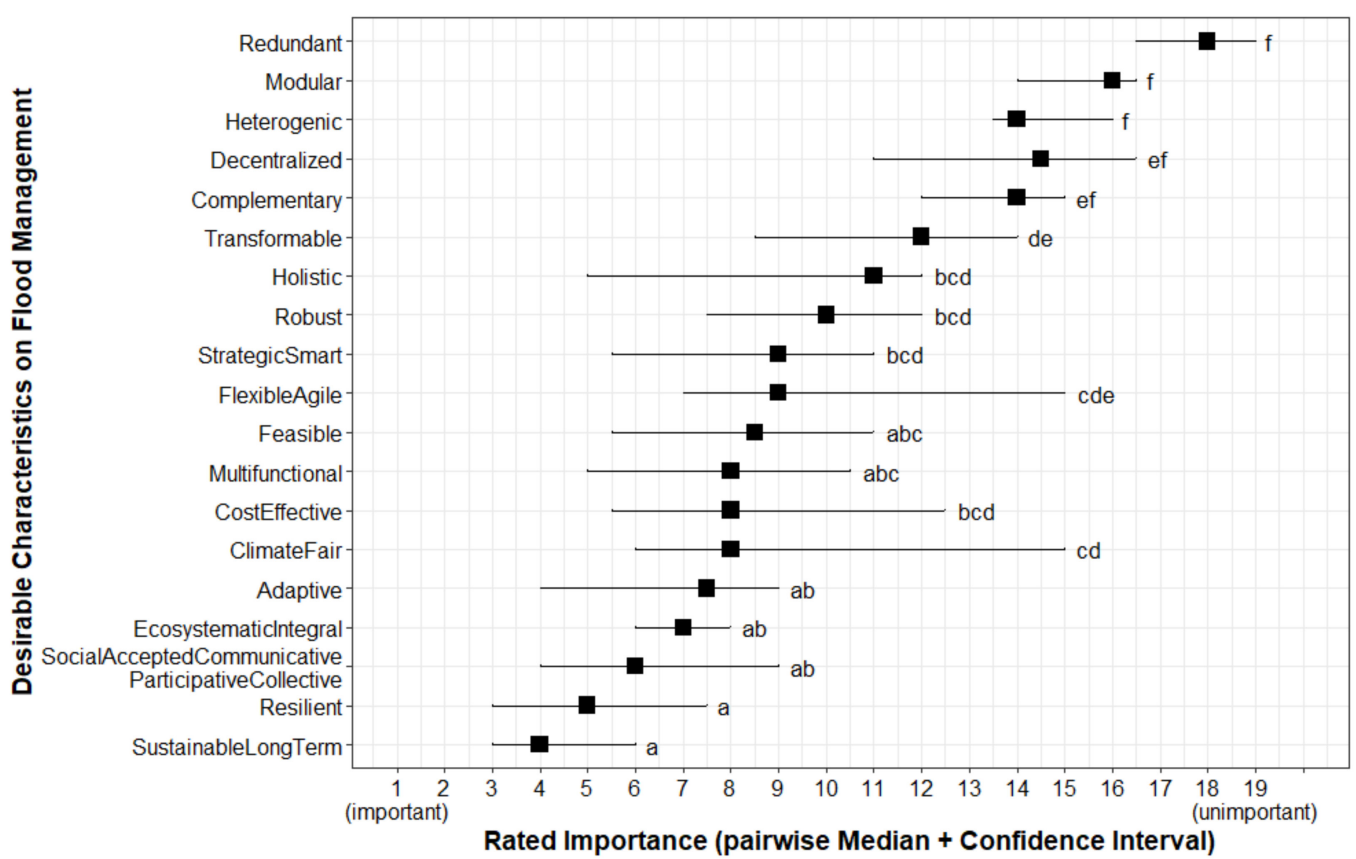

Figure 10. Statistical differentiation by the Friedman-Conover test of characteristics attributed to FM regarding their importance (Friedman $\chi_{\mathrm{fm}}$ and Kendall Wt test-statistics: $p<2.2 \times 10^{-16}, \mathrm{df}=18, \chi_{\mathrm{fm}}=156.74, \mathrm{Wt}=0.311$ ). Ratings of characteristics sharing a letter (e.g., "a" in Resilient and Feasible) could not be statistically differentiated. 


\subsection{Comparing the Findings between the Literature Review and Expert Survey}

Discrepancies became visible when comparing the survey ratings on the applicability and prioritization of FM measures and phases with the literature (Table 6). First, considering the prioritization, experts rated phases of the risk analysis and those of prevention, as well as early warning systems and emergency measures, as having a high priority. In the literature, major references on phases in the FM cycle were made with regards to preventive and precautionary measures, along with emergency measures and data analysis, modeling, and mapping (="hydro-geo information").

Table 6. Synthetic comparison between written and expert-based knowledge about flood management in rural mountainous areas.

\begin{tabular}{|c|c|c|}
\hline & Literature Review & Expert Survey \\
\hline Scale & Local to (supra-)regional & Local $>$ regional $>>$ Supraregional \\
\hline Technical feasibility & Easy to Complex & Not available \\
\hline Functionality & $\begin{array}{l}\text { Low and negative (Structural) } \\
\text { High and positive (Non-Structural) }\end{array}$ & $\begin{array}{c}\text { Low and Flood reduction (Structural) }> \\
\text { High and Multiple Benefits } \\
\text { (Non-Structural) }\end{array}$ \\
\hline Efficiency/Applicability & High $>>$ Low & Average, Well, and Totally Applicable \\
\hline $\begin{array}{l}\text { Phase with knowledge } \\
\text { available/High Priority }\end{array}$ & $\begin{array}{l}\text { Disaster Risk Reduction and } \\
\text { Risk Analysis }\end{array}$ & $\begin{array}{l}\text { Disaster Risk Reduction and } \\
\text { Risk Analysis }\end{array}$ \\
\hline Knowledge missing/Low Priority & $\begin{array}{c}\text { Building Codes and Event } \\
\text { Documentation, Recovery (Phases) }\end{array}$ & $\begin{array}{l}\text { Building Retrofitting, Training or Excises } \\
\text { and Insurance, Recovery (Phases) }\end{array}$ \\
\hline Recommendation & $\begin{array}{l}\text { Socio/-ecological, Cost-Effective, } \\
\text { Sustainable/Long-term, Complementary }\end{array}$ & $\begin{array}{l}\text { Ecologically integrated, Social, Adaptive, } \\
\text { Sustainable/Long-term, Resilient }\end{array}$ \\
\hline
\end{tabular}

Considering the applicability, "compensation systems" or "emergency preparation" were rated with good applicability for ERMAs, while the phase of insurance or emergency measures were rated as less important. Event documentation was rated as unimportant, but the corresponding measure "inclusion of knowledge and provision of education" was rated as very suitable for ERMAs. Additionally, natural water retention received a very high rating as a phase in the FM cycle, but its applicability in ERMAs (="soft flood water retention") was considered to be low. Nevertheless, it should be noted that NBS such as "sponge vegetation restoration" or "terrestrial ecosystem and habitat restoration" were judged to be well applicable. Likewise, warning systems and engineered solutions received low-rated applicability compared to a high rating of the phases early warning systems and technical flood defense. Emergency measures received medium importance, whereas corresponding "mobile embankments" were evaluated as rather unsuitable for ERMAs. The phases of data analysis, modeling and mapping, land use regulations, risk assessment and evaluation of measures, and natural water retention were found to be both important and very applicable or suitable for ERMAs.

When comparing measures for the different areas (SDS-1 to SDS-3), it is worth noting that experts showed greater knowledge than the publications. All three SDS missed many measures, such as information about instrumental solutions, and especially "mobile embankments" and "analysis of management practices". However, knowledge about functionalities was especially scarce in relation to the technical feasibility of measures, both in the literature review and in the expert surveys.

Regarding important characteristics of FM, the literature findings and the results of the experts survey largely coincided. For example, "ecologically integrated", "social", and "sustainable, long-term" were mentioned most often or as very important in the literature and by experts. "Redundant", "robust", "modular", "transformable", and "heterogenous" were indicated as unimportant in both the literature and the survey. "Climate-fair", "resilient", and "feasible" were considered important characteristics in the surveys but 
showed few mentions in the assessed literature. It is also notable that characteristics such as "complementary", "holistic", and "decentralized", were classified as less important in the survey but were mentioned far more frequently in the assessed literature. In the midfield of both analyses were characteristics such as "strategic/smart", "multifunctional", and "flexible/agile".

\section{Discussion}

The study presented an overview of the scientific knowledge available from publications and experts (incl. EU-funded projects) to advise the implementation of suitable FM measures in ERMAs. The hypothesis about scientific boundaries hindering the implementation of flood measures and management in ERMAs could be partly rejected. The study showed that both sources of knowledge are available and encouraging the implementation of non-structural solutions. These sources define such solutions as being sufficiently applicable, cost-effective, multifunctional with efficient flood risk reduction, and having a great potential for large-scale implementation. Considering the environmental effect of engineered solutions, the assessment of European and non-European publications (SDS-1 vs. SDS-2) was conflicting. In OMA (SDS-3), engineered solutions were assessed as being potentially either beneficial or damaging to the environment. The associated feasibility and implementation costs varied. Interestingly, NBS were classified as environmentally friendly in Europe and mostly damaging the environment outside Europe for the observed cases.

\subsection{Addressing the Causes Instead of the Symptoms}

The study showed that more knowledge is available for the phase "disaster risk reduction" than for "recovery". The focus on pre-flood event phases corresponds to the particular environmental conditions and flood characteristics in mountain regions. These make the use of warning systems as short-term actions difficult due to the very sudden and sometimes very severe onset of flash floods and riverine floods [27,28,103], while in Japan, 90\% of flood damage could be reduced despite increasing rainfall [104]. Furthermore, studies demonstrated that preventive and precautionary phases should be given greater focus over reactive and recovery phases in disaster management [105-107]. A reason for this statement is the higher costs incurred by recovery measures after a catastrophic flood event which potentially could be avoided if precautionary measures were taken $[106,108]$. In the context of climate change, namely, the unpredictable change of weather patterns with an expected increase of flood severity and frequency, a focus of FM design on precautionary measures is highly recommended [7]. The approach of addressing the causes instead of the effects of a natural hazard can be achieved through passive, permanent, as well as temporary structural as well as non-structural implementations of measures [61]. Furthermore, the results from the experts survey and literature analysis indicate a trend towards preventive FM in the scientific community [58].

While the documentation of historical events is of little help to predict floods, especially due to land use and climate change, modeling can highly improve the estimation of risks. Increased use of electro-technical systems (e.g., remote sensing and geospatial information systems [24,109], WeSenselt [110]) can be supported by continued technological innovation, increased capacity, and computational performance [24,32]. In addition, societal awareness of the risk and willingness to live in a more nature-friendly way may facilitate the transition and understanding of, e.g., building and land use regulations (private houses cannot be built everywhere). Despite great investments and more precautions, complete flood protection will not be possible [64,111], which is why reactive and post-flood measures should not be neglected, especially during strong and rare flood events [112]. This is due to, first, the predictability of flood events, which is fraught with uncertainty [58], second, the capacity limits of non-structural measures [34], and third, the catastrophic failure possibilities of structural measures, e.g., dam breakage [27,44,47,103]. The lack of FM analyses found in the literature review on FM in mountain areas may be explained by the fact that FM can also be handled without risk analysis [113]. The overview on FM in 
North American rural mountain regions attributes the challenges in FM and difficulties of flood resilience to, among other things, the complex conditions in these regions, including future conditions, insufficient data and infrastructure, and lack of long-term governance structures [24]. Information-based systems, measure failures, and maintenance in particular are also seen to be hampered by the difficult accessibility of rural mountain regions as challenges, while technological advances, e.g., in monitoring measures, data dissemination, communication networks, and forecasting, might provide relief [24]. Shortcomings in North American FM of rural mountain areas were found also for FM in other geographical areas $[24,31,32,111]$.

Emergency measures such as mobile protection systems have very limited potential in rural mountainous areas. For example, dams made of sandbags require a lot of personnel, time, and materials during a disaster [103] and can only be implemented by physically fit people [114]. These are possible reasons for the poor suitability of these protection systems in rural mountain regions, especially since the construction would have to happen very quickly during the sudden flood events. Therefore, more consideration of socio-demographic information in FM strategy development is recommended [115,116]. Instrumental FM measures, such as financial aid, are also necessary because some population groups are privately unable to make a sufficient contribution to FM by protecting themselves and recovering after perturbations [116].

\subsection{Natural Solutions as Cost-Efficient Measures}

The results of the study showed that natural solutions in ERMAs are cost-effective. In comparison to measures implemented in OMAs, they are eventually characterized as "cheap". This may be explained by the reduced number of owners in rural mountainous area. However, even in lowlands, floodplain restoration is considered as having a higher monetary value than engineered or structural measures [117]. Furthermore, FM requires minimal resource expenditure by using nature's regional capacities [32]. For example, forest management is 5 to 10 times cheaper than implementing structural solutions [12]. Regular maintenance is needed to ensure the effectiveness and functionality of engineered measures, which makes natural measures cost-effective only in the long term [31,111]. In this context, maintenance also includes adapting and modernizing the measures to the development trends of flood severity [32]. Under natural circumstances, it would be possible to predict the future behavior of a landscape feature, such as a river, from its flood history [1]. In Europe, this is likely to be complicated and only possible to a limited extent for a short period of time $[10,19]$.

\subsection{Natural Solutions as Multifunctional Measures}

As shown in this study, both natural and structural solutions are considered operational for rural mountain regions, with more favorable suitability on the side of NBS. NBS can also address other gravity-related natural phenomena $[19,118]$. Looking at the literature, decentralized natural measures are described as easy to implement, with positive ecological, economic, and aesthetic effects, and they are effective in flood reduction when used in a mosaic-like network [44]. Surprisingly, non-European publications suggested that natural measures may also damage the environment (e.g., increasing the risk of drought through pine stand establishment [69] or loss of biodiversity through the reforestation of grassy biomes [119]). Further research should investigate the unexpected damages to the environment and address them. It is expected that damages are short term and caused by massive perturbations of the ecosystem during restoration works [120], which may result in negative long-term effects such as on biodiversity. On the other hand, studies highlight that structural solutions are not just damaging the environment but also increasing the hazard (e.g., $[45,49,72,121])$. However, structural solutions are evolving to become more environmentally friendly. For example, structural measures can be designed as low-impact riparian structures [23], ecologically sensitive dams [66], planted/navigable dikes [122-124], or with living weirs [125]. This allows for more functions to be combined 
in one measure and compensate for the restricted applicability of natural measures in urban areas. Furthermore, the studied literature revealed that the outscaling of solutions applied in urbanized settings should be applied with caution.

The special conditions in mountain regions make it indispensable to use a variety of different FM measures, especially recommended for European mountain ranges [31,62] and in view of climate change and increasing flood frequency and severity $[47,49,66]$, as well as efficient and socio-economically justified design [29,112]. This can be attributed in part to the fact that restoring natural conditions is difficult in ERMA and engineered measures are neither socio-ecologically nor easily transferable to other regions [44]. For example, dike relocation turns out to be feasible but spatially limited, and river restoration turns out to be rapidly effective [37]. To some extent, a combination of engineered and natural solutions is possible $[6,19,118]$. Such heterogeneous landscapes can be very effective in reducing rapid runoff and an alternative to complete landscape afforestation [23,126], especially when considering wetlands, grasslands, etc. [119]. Looking elsewhere in the world, it is also possible to make heterogeneous landscapes multifunctional [127].

Public participation in FM is also limited by spatial constraints and land use requirements $[47,115,128]$. Therefore, a general call for more instrumental measures is made $[7,32]$. For example, a standardized compensation system is suggested by the literature [79]. Such an approach would be worthwhile for all parties involved and affected. Studies demonstrated that flood-adapted building construction reduces damage from $10 \%$ to $100 \%$ on valuable property $[47,61,112,129]$. The absence or low number of insurance or compensation schemes is also criticized [7] and has been reflected in the literature review and results from the expert survey. However, public-private FM should be pursued with the participation of all relevant individuals and entities, as governments alone cannot provide complete flood protection [7,24,32,122,130]. Examples of such whole-of-society disaster management approaches include the Sendai Framework for Disaster Risk Management, the Partnership for Environmental and Disaster Risk Reduction (PEDRR), the World Water Forum, and the IUCN Water and Nature Initiative (WANI) [131]. The State Disaster Event Insurance System NFIP or the Napa River Flood Protection Project may be used for guidance in this regard [24,44], as well as the EU Commission's 2004 action thread [113] and the Flood Framework Directive 2007/60/EC [132]. State-led flood mitigation measures should be linked to end land degradation and the promotion of regenerating natural landscapes, such as floodplains and green infrastructure, as well as other nature-based and basin-wide solutions with multiple ecosystem services and disaster applications [6,34].

\subsection{Natural Measures with Great Large-Scale Implementation Potential}

Floods can affect a large area, and this is the reason for FM to be planned on a largescale (watershed scale) [128]. In smaller watersheds, special attention must be paid to freeing up the small water storage capacities for subsequent water intakes [22,132]. Smallscale NBS are considered insufficient, especially under the different aspects of climate change but also in relation to reducing runoff and pollutant control. However, small near-natural retention basins can be easily integrated into national road networks [73]. Nevertheless, it must be kept in mind that due to land use pressures in some regions, such as in Europe, instrumental measures are needed to enable large scale implementations [133]. Tools developed in Sweden [134] and Germany [135], or pedo-geological maps [136] and stream management concepts [58,133] can facilitate the FM planning in this regard. Additionally, more emphasis should be given to large-scale, interconnected, and combined measures (NBS chain) [22] both in research and in practice due to capacity limits in small retention basins and the complex implementation of larger NBS chains [12,34]. Nevertheless, when measures or functions are combined, vulnerabilities may occur at interfaces between the measures and structures or settlements that need to be addressed [16]. Effectively implemented FM, however, could prevent up to $60 \%$ of flood damage [47]. In the rural mountain regions, NBS such as afforestation, reforestation, and slope stabilization, and for rivers, dike relocation and protective dams, can be particularly helpful in FM [34]. 
At best, this should be in place along the entire length of the stream [41]. Also, restricting residential development in floodplains, adapting existing structures, and strengthening building structures must be considered [137]. The implementation of measures should be designed around the impact areas of flood events (transboundary coordinated watershed management) rather than national, regional, or community boundaries, e.g., in the Netherlands through "water boards" [7,24,58]. The decentralization of FM at all levels, i.e., from types of measures to responsibilities and participation, can ensure resilient FM under the dynamic, complex, and peculiar conditions of rural mountain regions. Largescale implementation also allows for the reduction of the flood hazard before it arrives in vulnerable areas $[73,79,122,136,138]$, e.g., extend the concept of sponge city to landscape scale $[17,139,140]$. Therefore, on-land floodwater retention in areas upstream is recommended [58] and can be provided by decentralized FM [29] also in a quick manner [40] and effectively in cases of spatial and land use conflicts [23]. However, centralization has lowered the controllability and predictability of floods [9], and e.g., provoked the burial of the Isar River [121]. Future developments of rural mountain areas should prompt the rethinking of FM for these reasons [141].

\subsection{Social Boundaries as a Barrier to the Implementation of Natural Solutions}

While, historically, society was accustomed to living with flood risk and even taking advantage of floods (e.g., at the Nile River) [142], FM strategies developed between the 18th and 20th centuries and focused on fighting the flood instead of adapting to it. Shifting to a novel FM strategy based on NBS could pose difficulties in social acceptance, as societies are culturally shaped by engineered approaches. They are perceived as "looking efficient". NBS should be easily accepted by the public because of the societal co-benefits but are still perceived by laypeople as having limited flood mitigation effects [143]. Widespread awareness of the attributes of FM should therefore be pursued [143,144]. Integrative FM will require public education and involvement for a successful implementation $[47,62,144]$. Nonetheless, the restoration of a socio-ecological system requires a willingness to compromise in society [46]. In addition, a "flood dementia" and shifting of responsibility quickly undermines societal "co-working" because persons not directly affected by flood damages underestimate the impact of a flood event, or external factors such as influence of climate change or mismanagement are blamed as the cause of floods $[62,145]$. Therefore, a culture of remembrance should be established before adapting to flood events [48]. Because values in a society change very slowly, there is a need for accompanying research and work, such as socio-hydrology, that addresses societal and hydrological developments equally [48].

In addition, knowledge about FM, e.g., by civil society, should be promoted more strongly and no longer be designed only for economic damage limitation, i.e., risk reduction and loss sharing [7,58]. The European Alpine Strategy captures such cross-regional cooperation [133]. Otherwise, the divergent FM of other regions in a water catchment area creates counterproductive effects [146]. Solutions at larger scales should therefore incorporate adaptive land use [127]. Resettlement, often as a last resort solution, is also considered feasible, moderately costly, and compatible [7,47], as in the case of the French coastal towns of Vendée and Charente-Maritime [147]. Avoiding risky and vulnerable areas for certain uses would be a first step to flood protection [47,49]. Especially when economic aspects come into play, only the legal minimum is usually required [7]. With greater involvement and encouragement of the private sector, "dormant" social potential in FM can come to fruition. Flood mitigation measures can be maintained by the community, as exemplarily applied in Japan [122]. Only such integration into community understanding and continuous monitoring of measures generates effective, socio-ecologically resilient FM [7]. In addition, FM should be about intervening in the socio-spatial spread of humans rather than nature and establishing strategic and autonomous FM with individual and societal behaviors [7]. Floods must be viewed as a holistic societal-ecological phenomenon in order to implement comprehensive FM. 


\subsection{Limitations of the Study}

This study provides an overview on the available published and personal knowledge about FM and in particular in the case of ERMA. The analysis of published knowledge was based on the mathematical closeness or association found for variables in the different MCA models. However, it should not be forgotten that by means of the MCA neither a statement about the nature nor the strength of the relations can be made. Nevertheless, it was shown that relations exist between certain profiles. In general, caution should be exercised in its interpretations. Individual cases can distort the correspondences, and missing data points can lead to strong discrepancies in the frequency and heterogeneity of profiles [148-150]. For example, one such outlier was observed in the SDS-2 (see [69]). Across all SDSs, and in $70 \%$ to $99 \%$ of the cases, FM had no information on their multifunctionalities, the effects on the runoff peak, or the range of effects or flood severity. In the case of only a single literature evidence, e.g., on the society-enhancing effects or runoff peak delays of $4800 \mathrm{~min}$, caution should be taken when interpreting the MCA output, too. In addition, most evidence for Europe is situated in Central Europe and is missing other European mountain regions such as the Scottish Highlands, Caucasus, or Pyrenees. In the case of the heterogeneous distribution of variables, it would need to be clarified whether homogenization, equal number, and mass of modalities would consolidate or improve MCA results. Thus, more balanced data would be beneficial for such an analysis. An imbalance can also be a consequence of publication bias, with more positive than negative or non-significant results being published [151]. Despite the dimensional reduction in the SDS through MCA, more than $80 \%$ data variability were explained in the first three dimensions with strong associations among modalities in the data on FM in different mountainous areas.

The contradictions of the coherence between consulted literature and experts described in Section 3.3 were attributed to the search procedure on relevant literature, but it also reflects the previous focus in research and practice on urban and lowland regions, as evident in, e.g., [61]. Furthermore, the discrepancies observed for important characteristics in FM assigned in the literature and from experts, some being more important or found less frequent, may be due to different focuses in research, study, or publication. In addition, there were notable differences between the characteristics of FM for Europe and those outside Europe, i.e., geographic effects. Climatic conditions and much more natural land cover in tropical mountain regions, as well as a focus on traditional and indigenous ecological knowledge in FM, might explain the observed differences between Europe and other regions of the world. More favorable environmental conditions outside of Europe enable the use of FM practices in mountain regions that cannot be adopted one-to-one in ERMAs.

Finally, the response rate for the survey was within the usual range of expectation, with approximately 30 usable survey questionnaires from approximately 200 people contacted, mostly from both universities and research institutions. This might explain the largely matching results for the literature analysis and surveys, but it also suggests extending future research to the administrative, cultural, social, and technical boundaries and include knowledge from, e.g., technical relief agencies, planning departments, or disaster crisis teams, who are missing from the assessment, may also explain the lack of information on short-term pre- and post-flood phases in the prioritization rating. The survey yielded first definable results, namely, drawing the scientific boundaries of FM in ERMAs, as measured by the indicators of agreement, but it would be preferable to undergo a second round of surveys to consolidate answers, as is usual for a Delphi process.

\section{Conclusions}

Structural solutions are facing major difficulties in protecting goods and people in a changing environment, namely under land use and climate change, population development, regional conditions, and hydro-meteorological evolutions. Particularly mountains are experiencing a great increase in flood risk. Changes in FM are needed. Non-structural 
measures such as natural solutions have been recognized as potential FM measures to adapt to a fast-changing environment. However, their implementations remain limited in non-urban mountainous areas. Strategies in FM depend on administrative, cultural, social, technical, and scientific boundaries. While pilot measures showed that technical knowledge exists and the European political agenda supports natural measures, what are the scientific boundaries supporting implementation? This study showed that scientific knowledge can support decision makers and is encouraging the implementation of nonstructural solutions because they are efficient, cost-effective, multifunctional, and have great potential for large-scale implementation. However, scientific boundaries exist for the implementation of FM in rural mountain areas. Scientific knowledge gaps remain for building- and training-related phases, as well as ecological and environmental issues. Furthermore, a lack of FM assessment and of knowledge about technical feasibility exist. Moreover, scientific boundaries should benefit from further studies on the general effect of measure on flooding, on the spatial effect range and on the reduction in peak discharge, and further research should focus on the recovery phase of FM in ERMAs. A major lack of knowledge concerns the development of high-potential electro-technical systems such as early warning or modeling and of assessment procedure of the co-benefits or multiple functionalities of non-structural solutions. Finally, an investigation on the effects of instrumental solutions is urgent.

Supplementary Materials: The following are available online at https:/ / www.mdpi.com/article/10 .3390/hydrology8040167/s1, Section S1: Survey pages, Section S2: Raw survey data, Section S3: Data set for Multiple Correspondence Analysis.

Author Contributions: Conceptualization, F.C. and A.Z.-H.; methodology F.C.; validation, A.Z.-H.; formal analysis, F.C. and A.Z.-H.; investigation, F.C.; data curation, F.C.; writing-original draft, F.C. and A.Z.-H.; writing-review and editing, F.C., A.Z.-H., G.L. and S.P.; visualization, F.C., A.Z.-H. and G.L.; supervision, A.Z.-H. and G.L.; project administration, S.P.; funding acquisition, S.P. All authors have read and agreed to the published version of the manuscript.

Funding: PHUSICOS project received H2020 Grant Agreement No. 776681.

Institutional Review Board Statement: The study involves statements from humans. Conducting and handling of the interviews, collected data, and maintaining privacy of persons follows the legal basis of the EU, REGULATION (EU) 2016/679 OF THE EUROPEAN PARLIAMENT AND OF THE COUNCIL of 27 April 2016 on the protection of natural persons with regard to the processing of personal data and on the free movement of such data and repealing GDPA Directive 95/46/EC (General Data Protection Regulation) and corresponding country-specific regulations for the Federal Republic of Germany-BDSG (new) from 2018. In line with the Research Ethics Procedures of the Technical University of Munich, the participants received written information on how the data would be used and were asked to give their consent to participate in the survey according to these guidelines.

Informed Consent Statement: Written informed consent was obtained from all subjects involved in the survey.

Data Availability Statement: The data presented in this study are available from Table A1 in Appendix A, and Supplementary Materials (Sections S2 and S3).

Acknowledgments: The authors would like to thank the interviewees as well as Joshua Huang and Marcelian Grace for editing the paper and designing the illustrations, respectively. We address best thanks to our colleagues and especially our project coordinator, Amy Oen.

Conflicts of Interest: The authors declare no conflict of interest. The funders had no role in the design of the study; in the collection, analyses, or interpretation of data; in the writing of the manuscript, or in the decision to publish the results. 


\section{Appendix A. List of Publications Used in the Systematic Literature Review}

Table A1. List of references used in the systematic literature review, for the MCA, phases of flood risk management cycle, and important characteristics for flood management.

\begin{tabular}{|c|c|c|}
\hline $\begin{array}{l}\text { Sources Used in the Multiple } \\
\text { Correspondence Analysis of } \\
\text { Sub-Data Sets }\end{array}$ & $\begin{array}{c}\text { Sources Used in the Assessment } \\
\text { of Prioritized Phases in Flood } \\
\text { Management Cycle }\end{array}$ & $\begin{array}{l}\text { Sources Used in the Assessment } \\
\text { of Important Characteristics for } \\
\text { Flood Management }\end{array}$ \\
\hline $\begin{array}{c}{[6,9,12,20-} \\
24,27,29,31,33,34,36,37,40,45- \\
47,52,61-63,65,67,69,70,73,78,102 \\
104,108,110,113-115,118,119,121 \\
122,126,128,129,132,133,136,138 \\
140,141,145,152,153,153-198]\end{array}$ & $\begin{array}{c}{[7,9,11-13,17,20,23,24,28,29,31,32} \\
34,36,40,43,44,46,47,49,58,61,70,73 \\
78,79,104,108,112- \\
114,116,118,129,131,135,136,138- \\
140,143-145,152,155,156,163,164 \\
173,175,177,192,198-207]\end{array}$ & $\begin{array}{c}{[1,7,9,11-13,16,17,19,20,22-} \\
24,29,31,32,34- \\
37,39,40,43,44,46,47,49,52,58,61,62, \\
66,73,78,102,104,108- \\
114,116,118,119,122,127- \\
136,138,139,143,144,146,152,176, \\
179,185,186,188- \\
190,192,197,199,203,204,206-219]\end{array}$ \\
\hline
\end{tabular}

\section{Appendix B. MCA Model Configurations}

Table A2. Final configuration of models used in the analysis of the literature data, in other words, sub-data sets (SDS) for flood management in (1) European rural mountain areas (ERMA), (2) nonEuropean rural mountain areas (NERMA), and (3) other mountain areas (OMA).

\begin{tabular}{|c|c|c|c|}
\hline & SDS-1 (REMA) & SDS-2 (RNEMA) & SDS-3 (OMA) \\
\hline Active Modalities & $\begin{array}{l}\text { Flood Severity, } \\
\text { General Flood } \\
\text { Mitigation Effect, } \\
\text { Effect on Flooding, } \\
\text { Measure Block, } \\
\text { Spatial Effect Range, } \\
\text { Effect on Peak } \\
\text { Discharge }\end{array}$ & $\begin{array}{c}\text { Measure Block, } \\
\text { General Flood } \\
\text { Mitigation Effect, } \\
\text { Effect on Peak } \\
\text { Discharge, Spatial } \\
\text { Effect Range, Effect } \\
\text { on Flooding, } \\
\text { Environmental Effect }\end{array}$ & $\begin{array}{l}\text { Spatial Setting, } \\
\text { General Flood } \\
\text { Mitigation Effect, } \\
\text { Effect on Flooding, } \\
\text { Measure Block, } \\
\text { Spatial Effect Range, } \\
\text { Effect on Peak } \\
\text { Discharge }\end{array}$ \\
\hline $\begin{array}{l}\text { Supplementary } \\
\text { Modalities }\end{array}$ & $\begin{array}{c}\text { Year Period, } \\
\text { Subregions, Measures, } \\
\text { Technical Ease, } \\
\text { Environmental Effect, } \\
\text { Economic Effect, } \\
\text { Societal Effect, Peak } \\
\text { Discharge Dilatation } \\
\text { Minutes, Peak } \\
\text { Discharge Reduction }\end{array}$ & $\begin{array}{c}\text { Year Period, } \\
\text { Subregions, Measures, } \\
\text { Technical Ease, Flood } \\
\text { Severity, Economic } \\
\text { Effect, Societal Effect, } \\
\text { Peak Discharge } \\
\text { Dilatation Minutes, } \\
\text { Peak Discharge } \\
\text { Reduction }\end{array}$ & $\begin{array}{c}\text { Year Period, } \\
\text { Subregions, Measures, } \\
\text { Technical Ease, } \\
\text { Environmental Effect, } \\
\text { Economic Effect, } \\
\text { Societal Effect, Peak } \\
\text { Discharge Dilatation } \\
\text { Minutes, Peak } \\
\text { Discharge Reduction, } \\
\text { Flood Severity }\end{array}$ \\
\hline
\end{tabular}

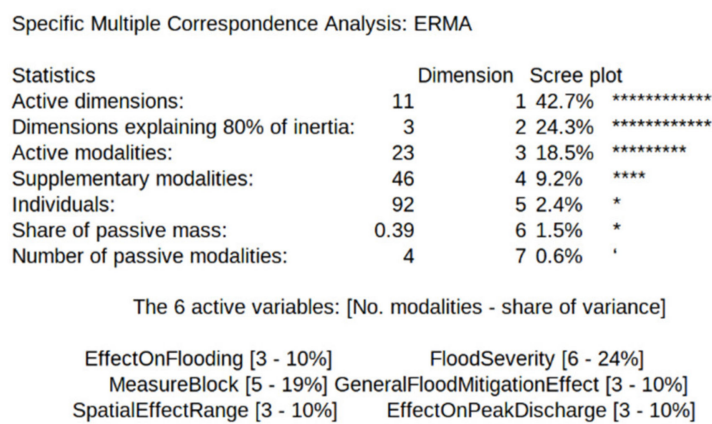

The 6 active variables: [No. modalities - share of variance]

EffectOnFlooding [3 - 10\%]

FloodSeverity [6 - 24\%]

MeasureBlock [5 - 19\%] GeneralFloodMitigationEffect [3 - 10\%]

SpatialEffectRange [3-10\%] EffectOnPeakDischarge [3 - 10\%]

Figure A1. MCA model of rural European mountainous areas (sub-data set 1). 
Specific Multiple Correspondence Analysis: NERMA

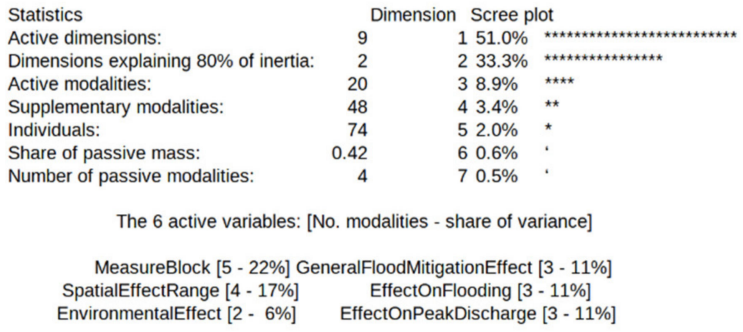

Figure A2. MCA model of rural non-European mountainous area (sub-data set 2).

Specific Multiple Correspondence Analysis: OMA

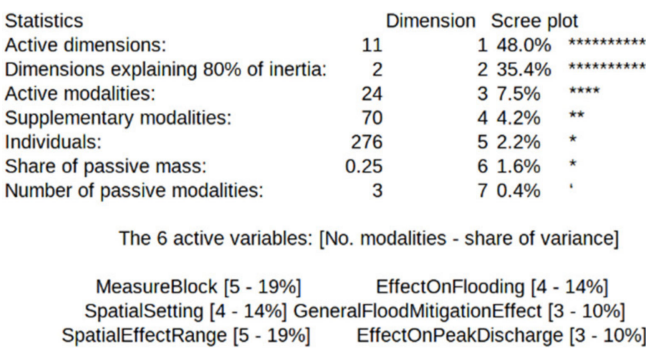

Figure A3. MCA model of Other Mountain Areas (sub-data set 3).

\section{Appendix C. Figures of Likert Percentages}

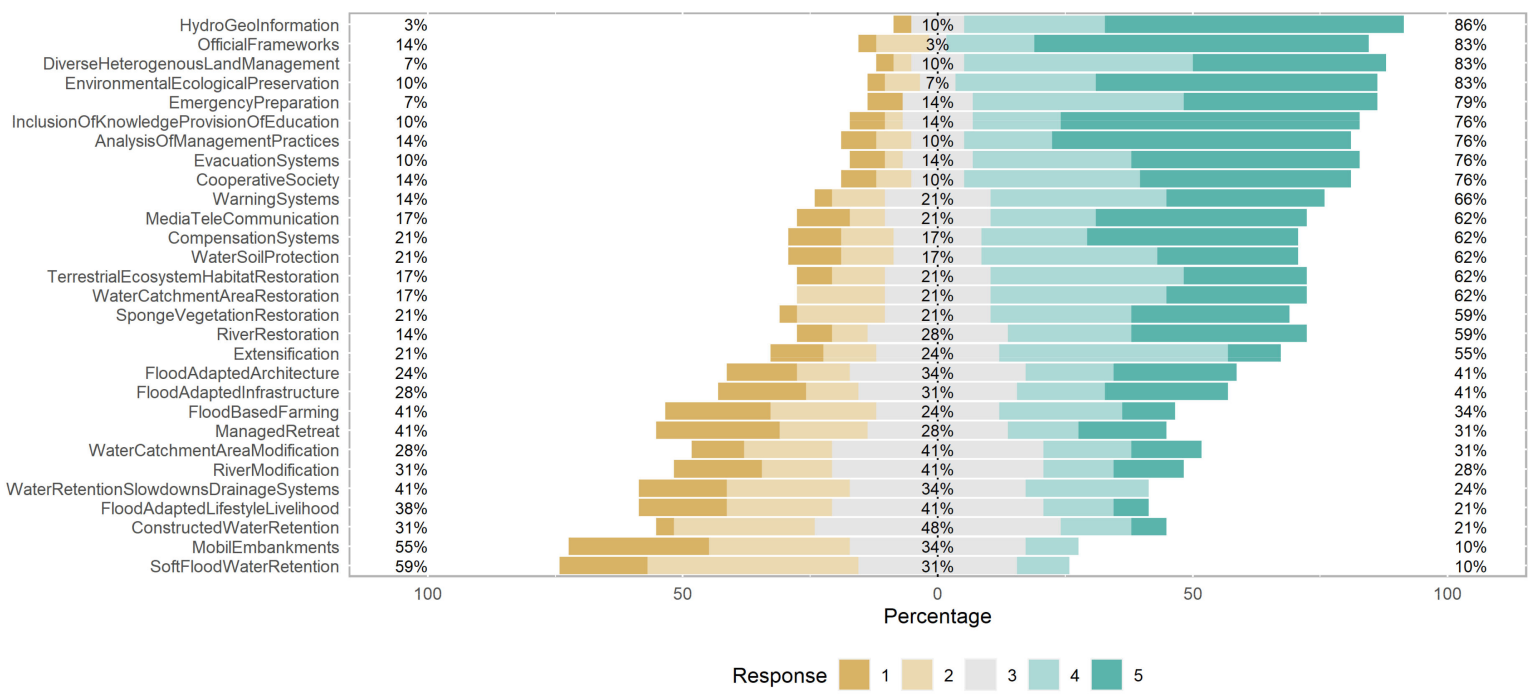

Figure A4. Percentages of Likert Scores for the applicability of flood measures from 1 being rarely applicable to 5 being totally applicable to rural mountain areas. 


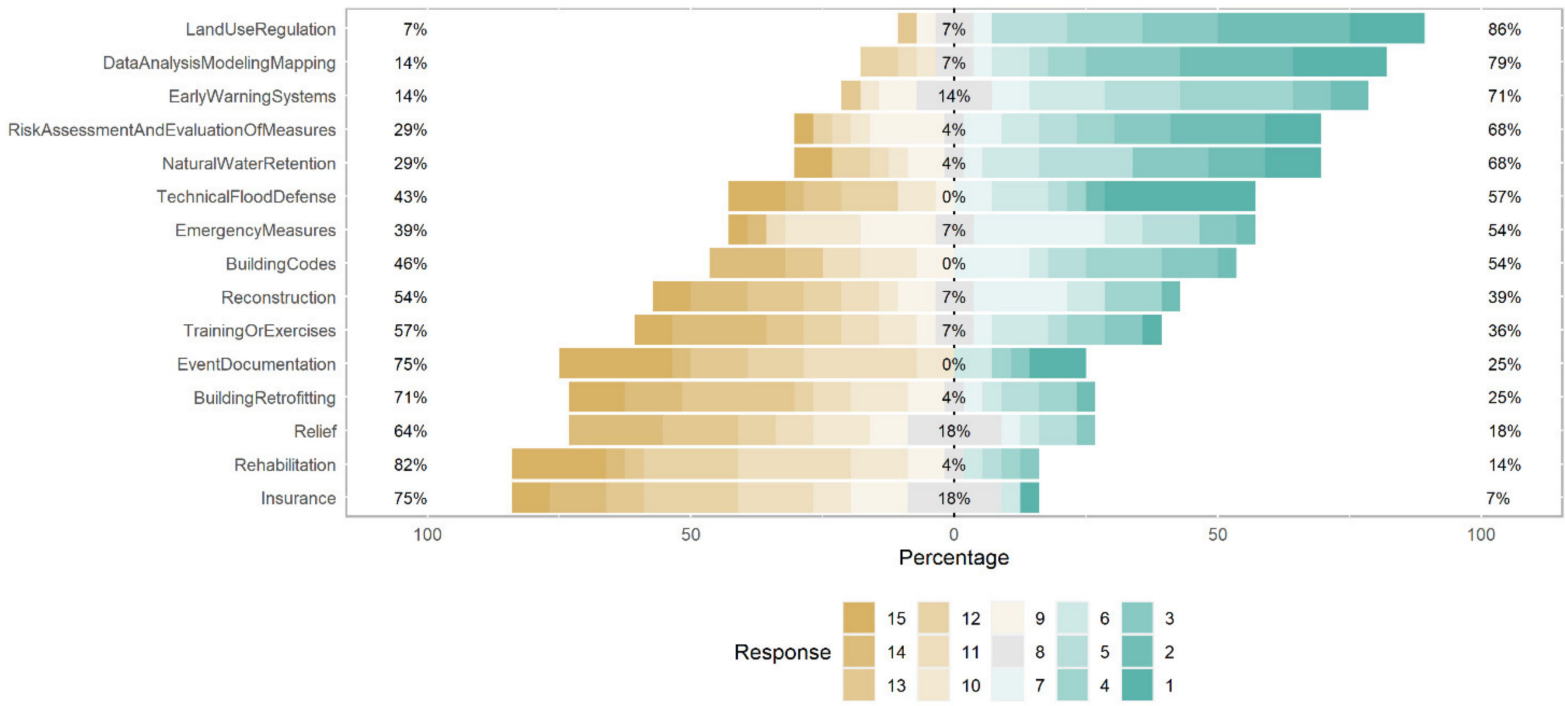

Figure A5. Percentages of Likert Scores for the prioritization of flood measure from early (1) to latest (15) in rural mountain areas.

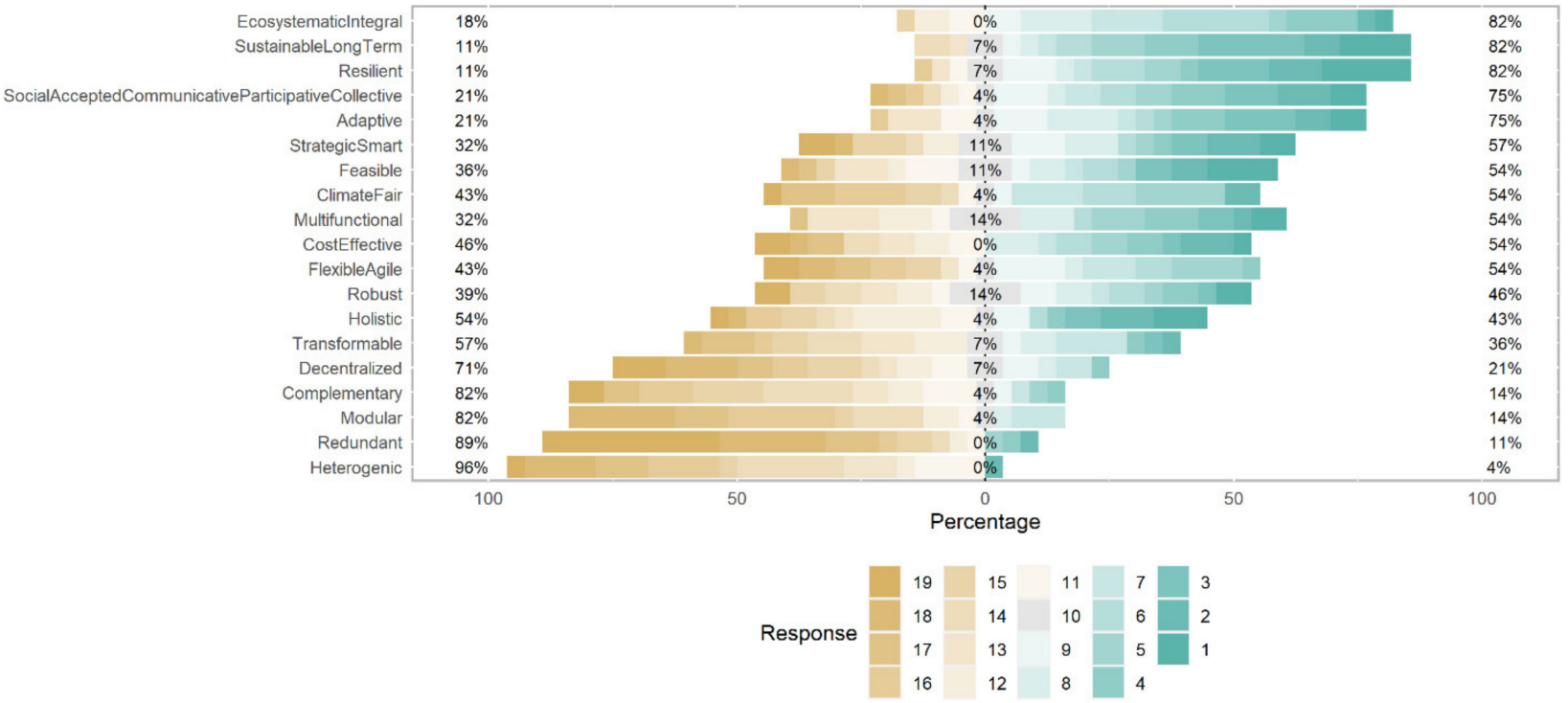

Figure A6. Percentages of Likert Scores for the important characteristics of flood management from important (1) to unimportant (19) in rural mountain areas. 


\section{Appendix D. Figures of Consensus}

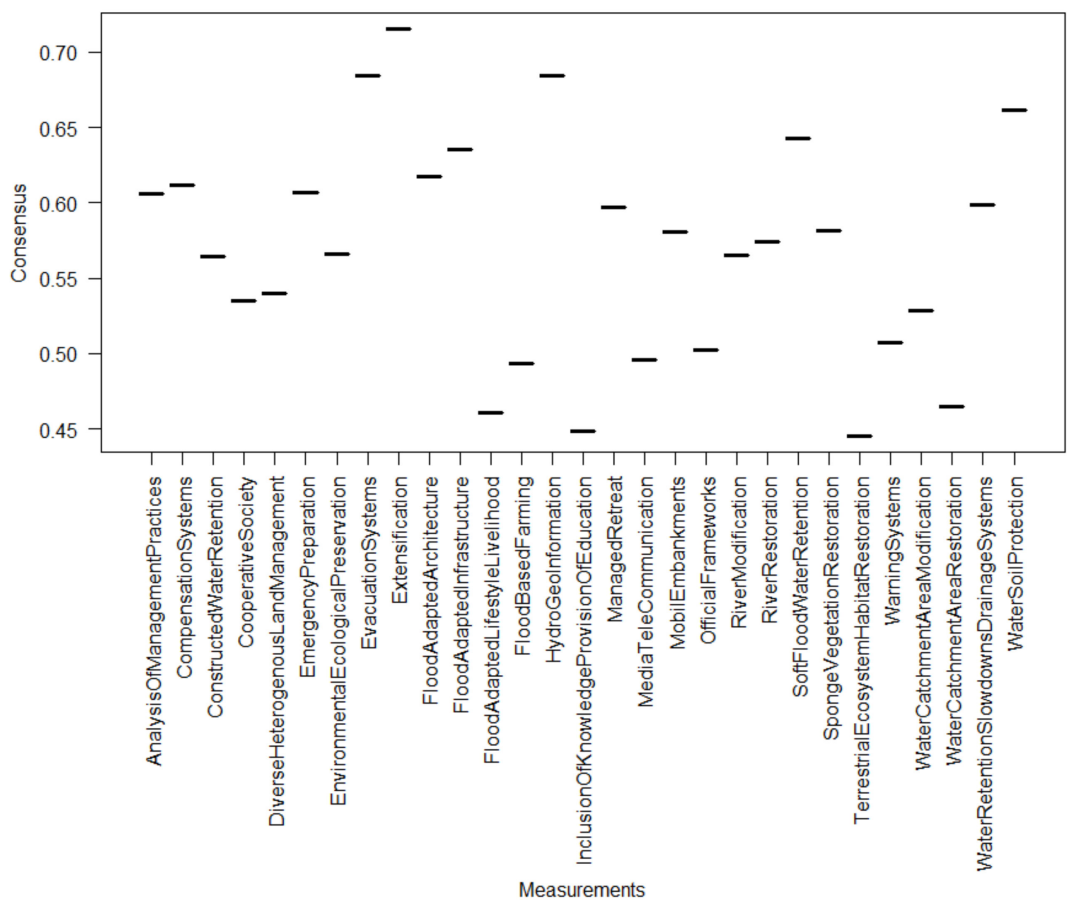

Figure A7. Agreement (consensus) among survey participants of the applicability of flood measures to rural mountain areas (the higher value, the more homogeneous the given responses; scale from 0 to 1$)$.

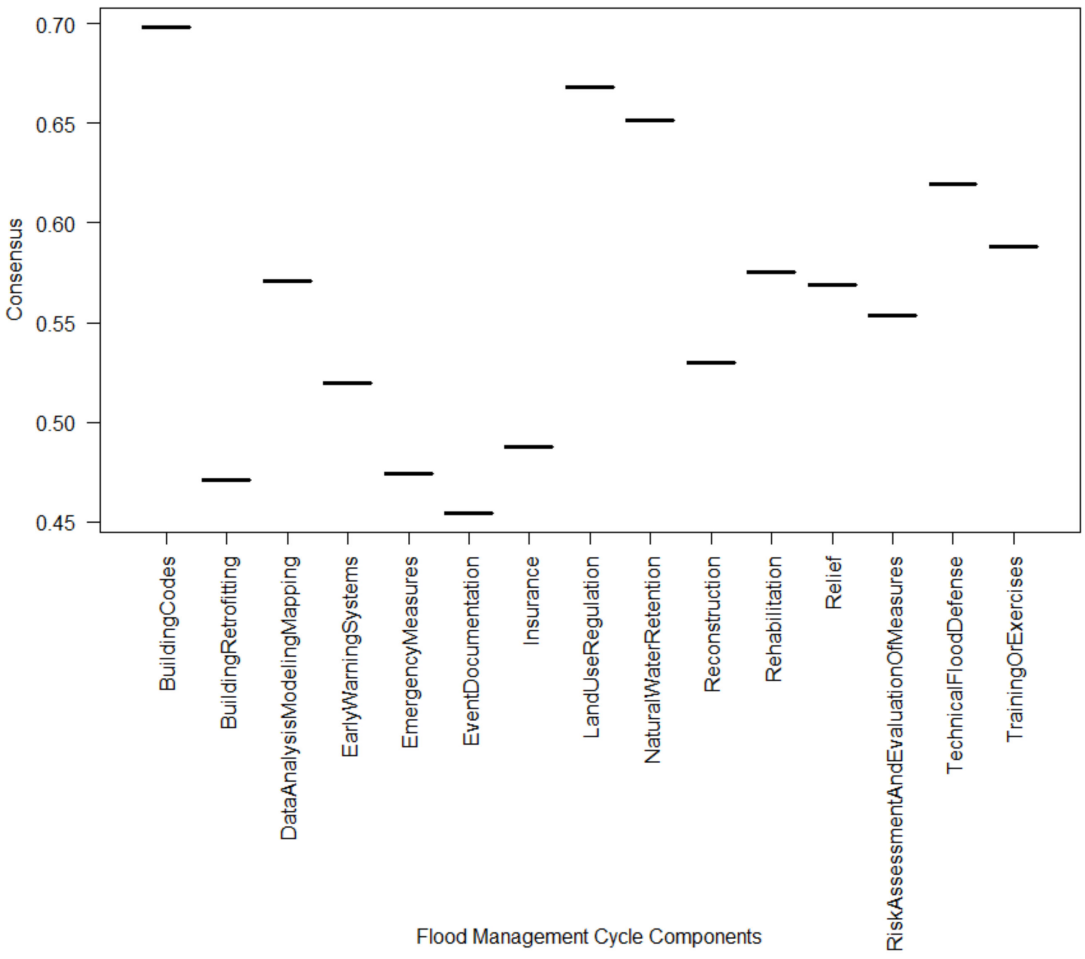

Figure A8. Agreement (consensus) among survey participants of the prioritization of flood management phases (components) to rural mountain areas (the higher value, the more homogeneous the given responses; scale from 0 to 1 ). 


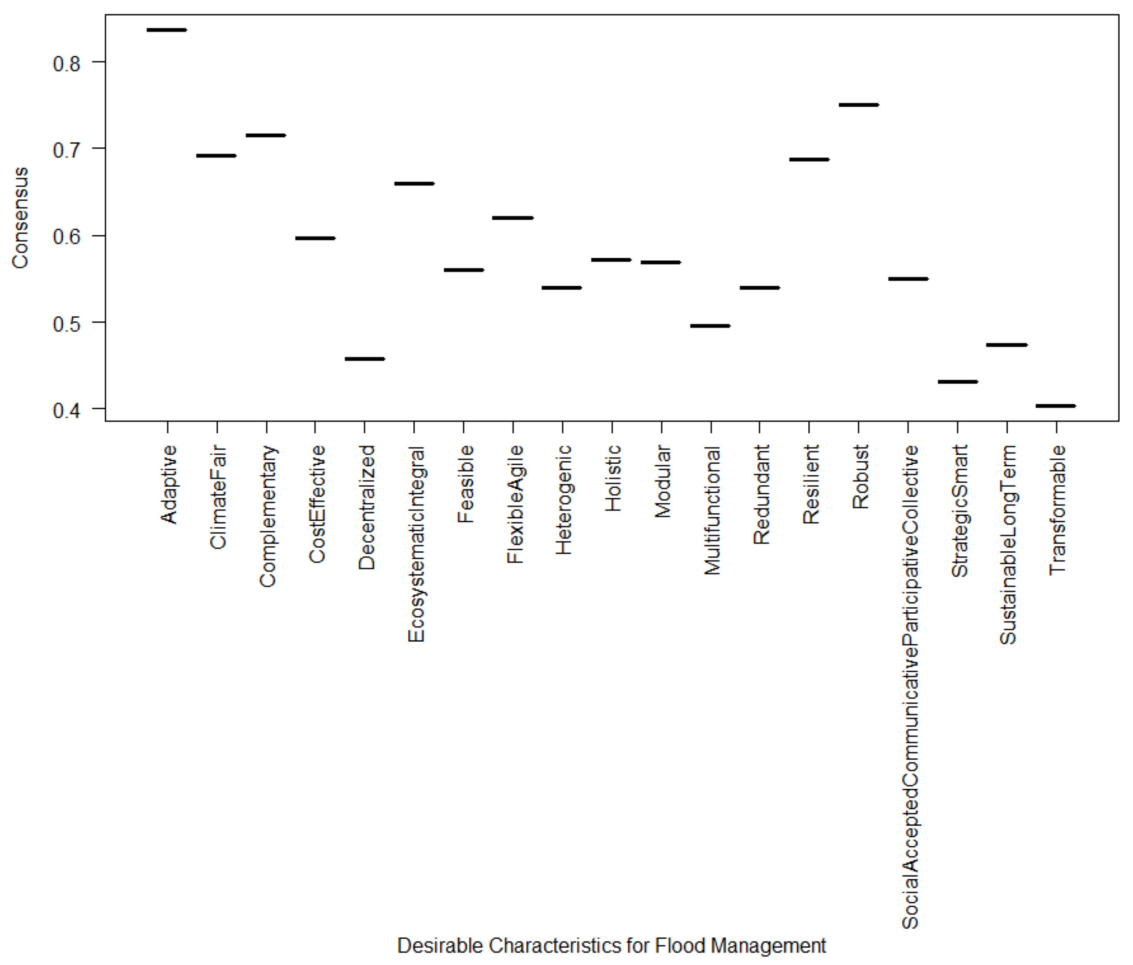

Figure A9. Agreement (consensus) among survey participants of the desirability of characteristics for flood management to rural mountain areas (the higher value, the more homogeneous the given responses; scale from 0 to 1 ).

\section{References}

1. Hughes, F.M. Floodplain Biogeomorphology. Prog. Phys. Geogr. Earth Environ. 1997, 21, 501-529. [CrossRef]

2. Nagl, G.; Schönauer, S. Ökologischer Hochwasserschutz-Raum Für Naturnahe Gewässer, Auen Und Feuchtgebiete—Schutz Für Die Menschen; Bund für Umwelt und Naturschutz Deutschland e.V. “BUND”, Ed.; BUNDhintergrund; Natur \& Umwelt Verlag: Berlin, Germany; Köln, Germany, 2002.

3. Jacob, J. The Response of Small Mammal Populations to Flooding. Mamm. Biol. 2003, 68, 102-111. [CrossRef]

4. Parolin, P.; Wittmann, F. Struggle in the Flood: Tree Responses to Flooding Stress in Four Tropical Floodplain Systems. AoB Plants 2010, 2010. [CrossRef] [PubMed]

5. Keller, K. Entwicklung Innovativer Tropfbewässerungssysteme zum Projektantrag RESS-125-010 PREFARM.Project Report. 2013. Available online: https://www.cleaner-production.de/fileadmin/assets/02WQ1121_-_Abschlussbericht.pdf (accessed on 19 August 2021).

6. Dige, G.; Kleeschulte, S.; Philipsen, C.; Schindler, S.; Sonderegger, G.; European Environment Agency. Exploring NatureBased Solutions: The Role of Green Infrastructure in Mitigating the Impacts of Weather-and Climate Change-Related Natural Hazards; Publications Office: Luxembourg, 2015; ISBN 978-92-9213-693-2.

7. Tempels, B. Flood Resilience: A Co-Evolutionary Approach. Residents, Spatial Developments and Flood Risk Management in the Dender Basin. In Planning; Ghent University, Faculty of Engineering and Architecture: Ghent, Belgium, 2016.

8. Żmihorski, M.; Pärt, T.; Gustafson, T.; Berg, Å. Effects of Water Level and Grassland Management on Alpha and Beta Diversity of Birds in Restored Wetlands. J. Appl. Ecol. 2016, 53, 587-595. [CrossRef]

9. Yang, B.; Young, R.F. Ecological Wisdom: Theory and Practice, 1st ed.; EcoWISE Innovative Approaches to Socio-Ecological Sustainability; Springer: Singapore, 2019; ISBN 9789811305719.

10. Belletti, B.; Garcia de Leaniz, C.; Jones, J.; Bizzi, S.; Börger, L.; Segura, G.; Castelletti, A.; van de Bund, W.; Aarestrup, K.; Barry, J.; et al. More than One Million Barriers Fragment Europe's Rivers. Nature 2020, 588, 436-441. [CrossRef]

11. European Commission. Flood Risk. Available online: Ec.europa.eu/environment/water/flood_risk/ (accessed on 10 January 2021).

12. International Union for Conservation of Nature. Nature-Based Solutions to Disasters. Available online: https://www.iucn.org/ resources/issues-briefs/nature-based-solutions-disasters (accessed on 9 January 2021).

13. Institute for Economics \& Peace. Ecological Threat Register 2020: Understanding Ecological Threats, Resilience and Peace; The Institute for Economics \& Peace: Sydney, Australia, 2020; p. 95. 
14. Munich, R.E. Overview of Natural Catastrophe Figures for 2016-The Year in Figures. Available online: https:/ / www.munichre. com/topics-online/en/climate-change-and-natural-disasters/natural-disasters/overview-natural-catastrophe-2016.html (accessed on 10 January 2021).

15. Perlman, H.; Evans, J. Der Wasserkreislauf, The Water Cycle, German. Available online: https://www.usgs.gov./water-scienceschool (accessed on 19 March 2021).

16. Van Ree, C.C.D.F.; Van, M.A.; Heilemann, K.; Morris, M.W.; Royet, P.; Zevenbergen, C. FloodProBE: Technologies for Improved Safety of the Built Environment in Relation to Flood Events. Environ. Sci. Policy 2011, 14, 874-883. [CrossRef]

17. Pavesi, F.C.; Barontini, S.; Pezzagno, M. "Sponge Land(Scape)": An Interdisciplinary Approach for the Transition to Resilient Communities. In Proceedings of the EGU General Assembly Conference Abstracts, 22nd EGU General Assembly, Online, 23 March 2020.

18. Paprotny, D.; Sebastian, A.; Morales-Nápoles, O.; Jonkman, S.N. Trends in Flood Losses in Europe over the Past 150 Years. Nat. Commun. 2018, 9, 1985. [CrossRef]

19. Debele, S.E.; Kumar, P.; Sahani, J.; Marti-Cardona, B.; Mickovski, S.B.; Leo, L.S.; Porcù, F.; Bertini, F.; Montesi, D.; Vojinovic, Z.; et al. Nature-Based Solutions for Hydro-Meteorological Hazards: Revised Concepts, Classification Schemes and Databases. Environ. Res. 2019, 179, 108799. [CrossRef]

20. Assmann, A. Die Planung Dezentraler, Integrierter Hochwasserschutzmaßnahmen-mit dem Schwerpunkt der Standortausweisung von Retentionsarealen an der oberen Elsenz, Kraichgau; Flurneuordnung und Landentwicklung in Baden-Württemberg; Landesamts für Flurneuordnung und Landentwicklung Baden-Württemberg: Kornwestheim, Germany, 1999.

21. Duwe, J. Hochwasser im Erzgebirge. Historische und aktuelle Überschwemmungen und ihr Schadensausmaß; Freie Universität Berlin, Geografisches Institut: Berlin, Germany, 2007.

22. Worreschk, B.; Wirksamkeit von Hochwasservorsorge und Hochwasserschutzmaßnahmen. (Eds.) Länderarbeitsgemeinschaft Wasser "LAWA", Schwerin. 2000. Available online: https://www.stmuv.bayern.de/themen/wasserwirtschaft/hochwasser/doc/ wirkungsabschaetzung.pdf (accessed on 19 August 2021).

23. Bölscher, J. Analyse Des Dezentralen Hochwasserrückhaltepotenzials Im Einzugsgebiet Der Natzschung/Načetínský Potok (Mittleres Erzgebirge) Unter Verwendung Des Niederschlag-Abfluss-Modells NASIM. Ph.D. Thesis, Freie Universität, Berlin, Germany, 2016.

24. Tullos, D.; Byron, E.; Galloway, G.; Obeysekera, J.; Prakash, O.; Sun, Y.-H. Review of Challenges of and Practices for Sustainable Management of Mountain Flood Hazards. Nat. Hazards 2016, 83, 1763-1797. [CrossRef]

25. Dittrich, S.; Worm, W. Dezentraler Hochwasserschutz; Schriftenreihe Sächs. Landesanst. Für Landwirtsch; Sächsisches Landesamt für Umwelt; Landwirtschaft und Geologie, LfULG: Dresden, Germany, 2006; p. 111.

26. Bittner, R.; Günther, K.; Merz, B. Naturkatastrophen in Deutschland; Ernst \& Sohn Special \& GFZ Helmholtz-Zentrum Potsdam: Berlin, Germany; Potsdam, Germany, 2009; pp. 7-10. Available online: https://gfzpublic.gfz-potsdam.de/rest/items/item_2396 51_1/component/file_239650/content (accessed on 19 August 2021).

27. Wright, J.M. Chapter 2, Types of Floods and Floodplains; Floodplain Management, Principles and Current Practices; FEMA Emergency Management Institute, Emmitsburg 2007. Available online: https://training.fema.gov/hiedu/docs/fmc/chapter\%20 2\%20-\%20types\%20of\%20floods\%20and\%20floodplains.pdf (accessed on 19 August 2021).

28. European Environmental Agency. Mapping the Impacts of Natural Hazards and Technological Accidents in Europe: An Overview of the Last Decade; Publications Office of the European Union: Luxembourg, 2010; Volume 13, ISBN 978-92-9213-168-5.

29. Gellweiler, I.; Seeling, S.; Hefczyk, A.; Hill, J. WaReLa Scientific Conference on Integrated Catchment for Hazard Mitigation; Universität Trier, Fachbereich VI, Abteilung Fernerkundung: Trier, Germany, 18 September 2007; p. 169.

30. European Commission. Floods and Their Impacts. Available online: https://ec.europa.eu/environment/water/flood_risk/ impacts.htm (accessed on 10 January 2021).

31. Luo, P.; He, B.; Takara, K.; Xiong, Y.E.; Nover, D.; Duan, W.; Fukushi, K. Historical Assessment of Chinese and Japanese Flood Management Policies and Implications for Managing Future Floods. Environ. Sci. Policy 2015, 48, 265-277. [CrossRef]

32. Rubinato, M.; Nichols, A.; Peng, Y.; Zhang, J.; Lashford, C.; Cai, Y.; Lin, P.; Tait, S. Urban and River Flooding: Comparison of Flood Risk Management Approaches in the UK and China and an Assessment of Future Knowledge Needs. Water Sci. Eng. 2019, 12, 274-283. [CrossRef]

33. Umweltbundesamt. Flüsse. Available online: https://www.umweltbundesamt.de/themen/wasser/fluesse\#hydromorphologie (accessed on 12 January 2021).

34. Ruangpan, L.; Vojinovic, Z.; Di Sabatino, S.; Leo, L.S.; Capobianco, V.; Oen, A.M.P.; McClain, M.E.; Lopez-Gunn, E. Nature-Based Solutions for Hydro-Meteorological Risk Reduction: A State-of-the-Art Review of the Research Area. Nat. Hazards Earth Syst. Sci. 2020, 20, 243-270. [CrossRef]

35. Restemeyer, B.; Woltjer, J.; van den Brink, M. A Strategy-Based Framework for Assessing the Flood Resilience of Cities-A Hamburg Case Study. Plan. Theory Pract. 2015, 16, 45-62. [CrossRef]

36. Stürck, J.; Poortinga, A.; Verburg, P.H. Mapping Ecosystem Services: The Supply and Demand of Flood Regulation Services in Europe. Ecol. Indic. 2014, 38, 198-211. [CrossRef]

37. Stoffel, M.; Wyżga, B.; Marston, R.A. Floods in Mountain Environments: A Synthesis. Geomorphology 2016, 272, 1-9. [CrossRef]

38. Blöschl, G.; Hall, J.; Viglione, A.; Perdigão, R.A.P.; Parajka, J.; Merz, B.; Lun, D.; Arheimer, B.; Aronica, G.T.; Bilibashi, A.; et al. Changing Climate Both Increases and Decreases European River Floods. Nature 2019, 573, 108-111. [CrossRef] 
39. European Environmental Agency. Floodplain Management: Reducing Flood Risks and Restoring Healthy Ecosystems. Available online: Eea.europa.eu/highlights / floodplain-management-reducing-flood-risks (accessed on 11 September 2021).

40. Länderarbeitsgemeinschaft Wasser "LAWA". Leitlinien Für Einen Zukunftsweisenden Hochwasserschutz Hochwasser -Ursachen Und Konsequenzen-; Länderarbeitsgemeinschaft Wasser "LAWA": Stuttgart, Germany, 1995; p. 30. Available online: https: / / www.lawa.de/documents/leitlinien_1552299715.pdf (accessed on 19 August 2021).

41. Bund für Umwelt und Naturschutz Deutschland "BUND". Naturschutz; Natur und Umwelt GmbH: Berlin, Germany, 2012; Volume 59.

42. De Wrachien, D.; Mambretti, S.; Schultz, B. Flood Management and Risk Assessment in Flood-Prone Areas: Measures and Solutions. Irrig. Drain. 2011, 60, 229-240. [CrossRef]

43. Thieken, A. Flood Risk Reduction in Germany: Lessons Learned from the 2002 Disaster in the Elbe Region. Summary of the Study; Grünewald, U., Kaltofen, M., Schümberg, S., Merz, B., Kreibich, H., Streitz, W., Dombrowsky, W.R., Deutsches Komitee für Katastrophenvorsorge, Eds.; Schriftenreihe des DKKV, Deutsches Komitee für Katastrophenvorsorge e.V: Bonn, Germany, 2004; ISBN 978-3-933181-34-3.

44. Ebinger, F.; Elsner, K.; Vogt, P. Ökoeffzienz-Analyse: Entwicklung eines Ansatzes zur Bewertung von Dezentralen Hochwasserschutzmaßnahmen; Arbeitsbericht, Albert-Ludwigs-Universität Freiburg, Institut für Forstökonomie: Freiburg, Germany, 2008 ; p. 46.

45. Dadson, S.J.; Hall, J.W.; Murgatroyd, A.; Acreman, M.; Bates, P.; Beven, K.; Heathwaite, L.; Holden, J.; Holman, I.P.; Lane, S.N.; et al. A Restatement of the Natural Science Evidence Concerning Catchment-Based 'Natural' Flood Management in the UK. Proc. R. Soc. Math. Phys. Eng. Sci. 2017, 473, 20160706. [CrossRef]

46. Achal, V.; Mukherjee, A. Ecological Wisdom Inspired Restoration Engineering; EcoWISE; Springer: Cham, Switzerland, 2019; ISBN 9789811343414.

47. Kreibich, H.; Bubeck, P.; Van Vliet, M.; De Moel, H. A Review of Damage-Reducing Measures to Manage Fluvial Flood Risks in a Changing Climate. Mitig. Adapt. Strateg. Glob. Chang. 2015, 20, 967-989. [CrossRef]

48. Commission for Interdisciplinary Ecological Studies, "KIOES". Umwelt und Gesellschaft. Herausforderung für Wissenschaft und Politik; Verlag der Österreichischen Akademie der Wissenschaften: Wien, Germany, 2018; Volume 8, p. 114.

49. Bechtol, V.; Laurian, L. Restoring Straightened Rivers for Sustainable Flood Mitigation. Disaster Prev. Manag. Int. J. 2005, 14, 6-19. [CrossRef]

50. Jessel, B.; Tschimpke, O.; Walser, M. Produktivkraft Natur; Aufl.; Hoffmann und Campe: Hamburg, Germany, 2009; ISBN 978-3-455-50140-7.

51. Lumbroso, D.; Ramsbottom, D.; Spaliveiro, M. Sustainable Flood Risk Management Strategies to Reduce Rural Communities' Vulnerability to Flooding in Mozambique: Sustainable Flood Risk Management Strategies. J. Flood Risk Manag. 2008, 1, 34-42. [CrossRef]

52. Highfield, W.E.; Brody, S.D. Evaluating the Effectiveness of Local Mitigation Activities in Reducing Flood Losses. Nat. Hazards Rev. 2013, 14, 229-236. [CrossRef]

53. Thaler, T.; Hartmann, T. Justice and Flood Risk Management: Reflecting on Different Approaches to Distribute and Allocate Flood Risk Management in Europe. Nat. Hazards 2016, 83, 129-147. [CrossRef]

54. Bubeck, P.; Kreibich, H.; Penning-Rowsell, E.C.; Botzen, W.J.W.; de Moel, H.; Klijn, F. Explaining Differences in Flood Management Approaches in Europe and in the USA-A Comparative Analysis: Differences in Flood Management Approaches. J. Flood Risk Manag. 2017, 10, 436-445. [CrossRef]

55. Wiering, M.; Kaufmann, M.; Mees, H.; Schellenberger, T.; Ganzevoort, W.; Hegger, D.L.T.; Larrue, C.; Matczak, P. Varieties of Flood Risk Governance in Europe: How Do Countries Respond to Driving Forces and What Explains Institutional Change? Glob. Environ. Chang. 2017, 44, 15-26. [CrossRef]

56. Kundzewicz, Z.W.; Hegger, D.L.T.; Matczak, P.; Driessen, P.P.J. Opinion: Flood-Risk Reduction: Structural Measures and Diverse Strategies. Proc. Natl. Acad. Sci. USA 2018, 115, 12321-12325. [CrossRef]

57. Jongman, B. Effective Adaptation to Rising Flood Risk. Nat. Commun. 2018, 9, 1986. [CrossRef]

58. Evers, M.; Mußbach, J.; Arndt, P.; Tischbierek, M. Integrative River Basin Management. Synergies and Target Areas in the Catchment Area of River Ilmenau (Final Report SAWA Ilmenau Project); Leuphana Universität Lüneburg \& Bartels Druck GmbH: Lüneburg, Germany, 2011; ISBN 978-3-935786-54-6. [CrossRef]

59. Reinhardt, C.; Bölscher, J.; Schulte, A.; Wenzel, R. Decentralised Water Retention along the River Channels in a Mesoscale Catchment in South-Eastern Germany. Phys. Chem. Earth Parts ABC 2011, 36, 309-318. [CrossRef]

60. Egli, M.; Poulenard, J. Soils of Mountainous Landscapes. In International Encyclopedia of Geography: People, the Earth, Environment and Technology; Richardson, D., Castree, N., Goodchild, M.F., Kobayashi, A., Liu, W., Marston, R.A., Eds.; John Wiley \& Sons, Ltd.: Oxford, UK, 2016; pp. 1-10, ISBN 978-0-470-65963-2.

61. Holub, M.; Hübl, J. Local Protection against Mountain Hazards-State of the Art and Future Needs. Nat. Hazards Earth Syst. Sci. 2008, 8, 81-99. [CrossRef]

62. Siegrist, M.; Gutscher, H. Natural Hazards and Motivation for Mitigation Behavior: People Cannot Predict the Affect Evoked by a Severe Flood. Risk Anal. Int. J. 2008, 28, 771-778. [CrossRef]

63. Watson, D.; Adams, M. Design for Flooding: Architecture, Landscape, and Urban Design for Resilience to Flooding and Climate Change; John Wiley \& Sons: Hoboken, NJ, USA, 2011; ISBN 978-0-470-47564-5. 
64. Hochwasserkompetenzzentrum e.V. Hochwasserpass. Available online: https://www.hochwasser-pass.com/Hochwasser (accessed on 10 January 2021).

65. Garrote, J.; Díez-Herrero, A.; Bodoque, J.; Perucha, M.; Mayer, P.; Génova, M. Flood Hazard Management in Public Mountain Recreation Areas vs. Ungauged Fluvial Basins. Case Study of the Caldera de Taburiente National Park, Canary Islands (Spain). Geosciences 2017, 8, 6. [CrossRef]

66. Peters, R. The European Agricultural Fund for Rural Development: Examples of Project Linkages with Other EU Funds; European Agricultural Fund for Rural Development, Publications Office: Brussel, Belgium, 2012; ISSN 1831-936X.

67. Yuen, E.; Anda, M.; Mathew, K.; Ho, G. Water Harvesting Techniques for Small Communities in Arid Areas. Water Sci. Technol. 2001, 44, 189-195. [CrossRef] [PubMed]

68. Moher, D.; Liberati, A.; Tetzlaff, J.; Altman, D.G.; The PRISMA Group. Preferred Reporting Items for Systematic Reviews and Meta-Analyses: The PRISMA Statement. PLoS Med. 2009, 6, e1000097. [CrossRef] [PubMed]

69. Ford, C.R.; Laseter, S.H.; Swank, W.T.; Vose, J.M. Can Forest Management Be Used to Sustain Water-Based Ecosystem Services in the Face of Climate Change? Ecol. Appl. 2011, 21, 2049-2067. [CrossRef]

70. Lourenço, L.C. Mutirão Reflorestamento: Reforestation Collective Action. Available online: https://oppla.eu/casestudy/20067 (accessed on 10 January 2021).

71. Nicholson, A.; Wilkinson, M.; O’Donnell, G.; Quinn, P. Runoff Attenuation Features: A Sustainable Flood Mitigation Strategy in the Belford Catchment, UK. Area 2012, 44, 463-469. [CrossRef]

72. Merten, J.; Stiegler, C.; Hennings, N.; Purnama, E.S.; Röll, A.; Agusta, H.; Dippold, M.A.; Fehrmann, L.; Gunawan, D.; Hölscher, D.; et al. Flooding and Land Use Change in Jambi Province, Sumatra: Integrating Local Knowledge and Scientific Inquiry. Ecol. Soc. 2020, 25, art14. [CrossRef]

73. Wegner, H. Dezentraler Hochwasserschutz. Wasser Boden 1992, 44, 6-10.

74. Jordan, P. Großgliederung Europas nach kulturräumlichen Kriterien. Eur. Reg. 2005, 13, 162-173.

75. United Nations Statistics Division, “UNSD”. Standard Country or Area Codes for Statistical Use (M49). Available online: https://unstats.un.org/unsd/methodology/m49/\#geo-regions (accessed on 10 September 2021).

76. Yevjevich, V. Classification and description of flood mitigation measures. In Coping with Floods; Rossi, G., Harmancioğlu, N., Yevjevich, V., Eds.; NATO ASI Series; Springer: Dordrecht, The Netherlands, 1994; pp. 573-584, ISBN 978-94-011-1098-3.

77. Klimanavigator. Naturkatastrophen in Deutschland-Ein Überblick; Wie Können Wir Uns Schützen? Available online: https: //www.klimanavigator.eu/dossier/artikel/012154/index.php; (accessed on 12 January 2021).

78. Reinhardt, C.; Bölscher, J.; Imjela, R.; Schulte, A. Dezentraler Hochwasserrückhalt-Maßnahmen, Potentiale und ein Fallbeispiel aus dem Mittleren Erzgebirge. In Hochwasserdynamik und Risikomanagement-Neue Ansätze für bekannte Probleme? Schulte, A., Reinhardt, C., Dittrich, A., Jüpner, R., Lüderitz, V., Eds.; Shaker Verlag: Berlin, Germany, 2011; pp. 61-76.

79. Morris, J.; Beedell, J.; Hess, T.M. Mobilising Flood Risk Management Services from Rural Land: Principles and Practice: Flood Risk Management Services from Rural Land. J. Flood Risk Manag. 2016, 9, 50-68. [CrossRef]

80. Manderscheid, K. Sozialwissenschaftliche Datenanalyse mit R: Eine Einführung, 2nd ed.; Lehrbuch; Springer Fachmedien Wiesbaden GmbH: Wiesbaden, Germany; Heidelberg, Germany, 2017; ISBN 978-3-658-15902-3.

81. Blasius, J.; Georg, W. Clusteranalyse und Korrespondenzanalyse in der Lebensstilforschung: Ein Vergleich am Beispiel der Wohnungseinrichtung; ZA-InformationZentralarchiv Für Empirische Sozialforschung (Universität zu Köln): Cologne, Germany, 1992; pp. 112-133.

82. Diaz-Bone, R. Statistik für Soziologen, 4th ed.; UTB Basics; UVK Verlag: München, Germany, 2019; ISBN 978-3-8252-5071-3.

83. Pouyanfar, S.; Tao, Y.; Tian, H.; Chen, S.-C.; Shyu, M.-L. Multimodal Deep Learning Based on Multiple Correspondence Analysis for Disaster Management. World Wide Web 2019, 22, 1893-1911. [CrossRef]

84. Amador-Cruz, F.; Figueroa-Rangel, B.L.; Olvera-Vargas, M.; Mendoza, M.E. A Systematic Review on the Definition, Criteria, Indicators, Methods and Applications behind the Ecological Value Term. Ecol. Indic. 2021, 129, 107856. [CrossRef]

85. Marcillo-Delgado, J.C.; Alvarez-Garcia, A.; García-Carrillo, A. Analysis of Risk and Disaster Reduction Strategies in South American Countries. Int. J. Disaster Risk Reduct. 2021, 61, 102363. [CrossRef]

86. Zengul, F.D.; Zengul, A.G.; Mugavero, M.J.; Oner, N.; Ozaydin, B.; Delen, D.; Willig, J.H.; Kennedy, K.C.; Cimino, J. A Critical Analysis of COVID-19 Research Literature: Text Mining Approach. Intell.-Based Med. 2021, 5, 100036. [CrossRef]

87. Zingraff-Hamed, A.; Hüesker, F.; Albert, C.; Brillinger, M.; Huang, J.; Lupp, G.; Scheuer, S.; Schlätel, M.; Schröter, B. Governance Models for Nature-Based Solutions: Seventeen Cases from Germany. Ambio 2021, 50, 1610-1627. [CrossRef]

88. Batista-Foguet, J.M.; Mendoza, R.; Pérez-Perdigón, M.; Ruis, R. Life-Styles of Spanish School-Aged Children: Their Evolution over Time 1. Use of Multiple Correspondence Analysis to Determine Overall Trends over Time in a Sequential, Cross-Sectional Study. Advances in Methodology, Data analysis and Statistics; Ferligoj, A., Mrvar, A., Eds.; Metodološki Zvezki: Ljubljana, Slovenia, 2000; Volume 16, pp. 147-172.

89. D’Enza, A.I.; Greenacre, M. Multiple Correspondence Analysis for the Quantification and Visualization of Large Categorical Data Sets. In Advanced Statistical Methods for the Analysis of Large Data-Sets; Di Ciaccio, A., Coli, M., Angulo Ibanez, J.M., Eds.; Springer: Berlin/Heidelberg, Germany, 2012; pp. 453-463, ISBN 978-3-642-21036-5.

90. Avolio, M.; Montagnoli, S.; Marino, M.; Basso, D.; Furia, G.; Ricciardi, W.; de Belvis, A.G. Factors Influencing Quality of Life for Disabled and Nondisabled Elderly Population: The Results of a Multiple Correspondence Analysis. Curr. Gerontol. Geriatr. Res. 2013, 2013, 258274. [CrossRef] [PubMed] 
91. Greenacre, M.; Pardo, R. Subset Correspondence Analysis: Visualizing Relationships among a Selected Set of Response Categories From a Questionnaire Survey. Sociol. Methods Res. 2006, 35, 193-218. [CrossRef]

92. Dramalidis, A.; Markos, A. Subset Multiple Correspondence Analysis as a Tool for Visualizing Affiliation Networks. J. Data Anal. Inf. Process. 2016, 4, 81-89. [CrossRef]

93. Grau Larsen, A.; Ellersgaard, C.; Andrade, S. Package “soc.ca”; 9 February 2016. Available online: github.com/Rsoc/soc.ca (accessed on 19 August 2021).

94. Josse, J.; Husson, F. MissMDA: A Package for Handling Missing Values in Multivariate Data Analysis. J. Stat. Softw. 2016, 70, 1-30. [CrossRef]

95. Carpenter, J.; Kenward, M. Brief Comments on Computational Issues with Multiple Imputation. Unpublished Paper Retrieved from CiteSeerX. 2008. Available online: https: / / citeseerx.ist.psu.edu/viewdoc/download?doi=10.1.1.394.9545\&rep=rep1\&type= pdf (accessed on 19 August 2021).

96. Carpenter, J.R.; Smuk, M. Missing Data: A Statistical Framework for Practice. Biometr. J. 2021, 63, 915-947. [CrossRef]

97. Josse, J.; Chavent, M.; Liquet, B.; Husson, F. Handling Missing Values with Regularized Iterative Multiple Correspondence Analysis. J. Classif. 2012, 29, 91-116. [CrossRef]

98. Häder, M.; Häder, S. Delphi-Befragung. In Handbuch Methoden der Empirischen Sozialforschung; Baur, N., Blasius, J., Eds.; Springer Fachmedien Wiesbaden: Wiesbaden, Germany, 2019; pp. 701-707, ISBN 978-3-658-21307-7.

99. Tastle, W.J.; Wierman, M.J.; Dumdum, U.R. Ranking Ordinal Scales Using the Consensus Measure. Issues Inf. Syst. 2005, 6, 96-102.

100. Tastle, W.J.; Wierman, M.J. Consensus and Dissention: A Measure of Ordinal Dispersion. Int. J. Approx. Reason. 2007, 45, 531-545. [CrossRef]

101. Mangiafico, S.S. Summary and Analysis of Extension Program Evaluation in R, Version 1.18.8; Rutgers Coop. Ext.: New Brunswick, NJ, USA, 2016; pp. 16-22. Available online: rcompanion.org/documents/RHandbookProgramEvaluation.pdf (accessed on 19 August 2021).

102. Amini, A.; Ghazvinei, P.T.; Javan, M.; Saghafian, B. Evaluating the Impacts of Watershed Management on Runoff Storage and Peak Flow in Gav-Darreh Watershed, Kurdistan, Iran. Arab. J. Geosci. 2014, 7, 3271-3279. [CrossRef]

103. Massolle, C.; Lankenau, L.; Koppe, B. Emergency Flood Control: Practice-Oriented Test Series for the Use of Sandbag Replacement Systems. Geosciences 2018, 8, 482. [CrossRef]

104. Ikeuchi, K. Flood Management in Japan. Available online: https://www.mlit.go.jp/river//////basic_info/english/pdf/conf_ 01-0.pdf (accessed on 13 March 2012).

105. Deen, S. Pakistan 2010 Floods. Policy Gaps in Disaster Preparedness and Response. Int. J. Disaster Risk Reduct. 2015, 12, 341-349. [CrossRef]

106. Yadav, D.K.; Barve, A. Prioritization of Cyclone Preparedness Activities in Humanitarian Supply Chains Using Fuzzy Analytical Network Process. Nat. Hazards 2019, 97, 683-726. [CrossRef]

107. Titko, M.; Ristvej, J. Assessing Importance of Disaster Preparedness Factors for Sustainable Disaster Risk Management: The Case of the Slovak Republic. Sustainability 2020, 12, 9121. [CrossRef]

108. European Commission. How Local Action Can Boost Europe's Flood Resilience. Available online: https://ec.europa. eu/programmes/horizon2020/en/news/how-local-action-can-boost-europe\%E2\%80\%99s-flood-resilience (accessed on 11 September 2021).

109. Vojinovic, Z.; Keerakamolchai, W.; Weesakul, S.; Pudar, R.; Medina, N.; Alves, A. Combining Ecosystem Services with CostBenefit Analysis for Selection of Green and Grey Infrastructure for Flood Protection in a Cultural Setting. Environments $2016,4,3$. [CrossRef]

110. European Commission. Putting the Citizen at the Centre of Flood Prevention. Available online: https://ec.europa.eu/ programmes/horizon2020/en/news/putting-citizen-centre-flood-prevention (accessed on 13 January 2021).

111. EU Water Directors. Best Practices on Flood Prevention, Protection and Mitigation; Water Directors of the European Union: Brussels, Belgium, 2003.

112. Egli, T. Non Structural Flood Plain Management Measures and Their Effectiveness; Internationale Kommission zum Schutz des Rheins, Ed.; International Commission for the Protection of the Rhine (ICPR): Koblenz, Germany, 2002; ISBN 978-3-935324-47-2.

113. Schanze, J.; Zeman, E.; Marsalek, J. Flood Risk Management: Hazards, Vulnerability and Mitigation Measures; NATO Science Series, Series IV, Earth and Environmental Sciences; Springer: Dordrecht, The Netherlands, 2006; ISBN 978-1-4020-4596-7.

114. Liu, D.; Li, Y.; Fang, S.; Zhang, Y. Influencing Factors for Emergency Evacuation Capability of Rural Households to Flood Hazards in Western Mountainous Regions of Henan Province, China. Int. J. Disaster Risk Reduct. 2017, 21, 187-195. [CrossRef]

115. Scolobig, A.; De Marchi, B. Dilemma in land-use planning in flood prone areas. In Flood Risk Management: Extended Abstracts; Volume (332 Pages) + Full Paper CD-ROM (1772 Pages); Samuels, P., Huntington, S., Allsop, W., Harrop, J., Eds.; CRC Press: Hoboken, NJ, USA, 2008; p. 204, ISBN 978-0-203-88302-0.

116. Koks, E.E.; Jongman, B.; Husby, T.G.; Botzen, W.J.W. Combining Hazard, Exposure and Social Vulnerability to Provide Lessons for Flood Risk Management. Environ. Sci. Policy 2015, 47, 42-52. [CrossRef]

117. Perosa, F.; Gelhaus, M.; Zwirglmaier, V.; Arias-Rodriguez, L.F.; Zingraff-Hamed, A.; Cyffka, B.; Disse, M. Integrated Valuation of Nature-Based Solutions Using TESSA: Three Floodplain Restoration Studies in the Danube Catchment. Sustainability 2021, 13, 1482. [CrossRef] 
118. Moos, C.; Bebi, P.; Schwarz, M.; Stoffel, M.; Sudmeier-Rieux, K.; Dorren, L. Ecosystem-Based Disaster Risk Reduction in Mountains. Earth-Sci. Rev. 2018, 177, 497-513. [CrossRef]

119. Veldman, J.W.; Overbeck, G.E.; Negreiros, D.; Mahy, G.; Le Stradic, S.; Fernandes, G.W.; Durigan, G.; Buisson, E.; Putz, F.E.; Bond, W.J. Where Tree Planting and Forest Expansion Are Bad for Biodiversity and Ecosystem Services. BioScience 2015, 65, 1011-1018. [CrossRef]

120. Geist, J.; Hawkins, S.J. Habitat Recovery and Restoration in Aquatic Ecosystems: Current Progress and Future Challenges: Aquatic Restoration. Aquat. Conserv. Mar. Freshw. Ecosyst. 2016, 26, 942-962. [CrossRef]

121. Pugliese, F.; Caroppi, G.; Zingraff-Hamed, A.; Lupp, G.; Giugni, M. Nature-Based Solutions (NBSs) Application for HydroEnvironment Enhancement. A Case Study of the Isar River (DE). Environ. Sci. Proc. 2020, 2, 30. [CrossRef]

122. Shaw, R.; Uy, N.; Baumwoll, J. Indigenous Knowledge for Disaster Risk Reduction: Good Practices and Lessons Learned from Experiences in the Asia-Pacific Region; International Strategy for Disaster Reduction: Bangkok, Thailand, 2008; Volume 19.

123. Bhattacharyya, K. The Lower Damodar River, India: Understanding the Human Role in Changing Fluvial Environment; Advances in Asian Human-Environmental Research; Springer: Dordrecht, The Netherlands; New York, NY, USA, 2011; ISBN 978-94-007-0467-1.

124. Van der Meulen, J.; de Vries, M.; Olieman, M.; Venema, H.; Schelfhout, H. Willows for Less Expensive and More Beautiful Dikes. Water Matters Knowl. J. Water Prof. 2015, 2,1. Available online: https:/ /www.h2o-watermatters.com/includes/partials/ printArticle.php?ed=201511\&art=05_Artikel (accessed on 19 August 2021).

125. Deutsche Gesellschaft für Internationale Zusammenarbeit, “GIZ”. Solutions in Focus: Ecosystem-Based Adaptation from Mountains to Oceans. How People Adapt to Climate Change by Using Nature; PANORAMA Solutions for a Healthy Planet: Bonn, Germany; Eschborn, Germany, 2018.

126. Ryan, J.; McAlpine, C.; Ludwig, J.; Callow, J. Modelling the Potential of Integrated Vegetation Bands (IVB) to Retain Stormwater Runoff on Steep Hillslopes of Southeast Queensland, Australia. Land 2015, 4, 711-736. [CrossRef]

127. Vogt, N.; Pinedo-Vasquez, M.; Brondízio, E.S.; Rabelo, F.G.; Fernandes, K.; Almeida, O.; Riveiro, S.; Deadman, P.J.; Dou, Y. Local Ecological Knowledge and Incremental Adaptation to Changing Flood Patterns in the Amazon Delta. Sustain. Sci. 2016, 11, 611-623. [CrossRef]

128. Nordbeck, R.; Löschner, L.; Scherhaufer, P.; Hogl, K.; Seher, W. Hochwasserschutzverbände als Instrument der interkommunalen Kooperation im Hochwasserrisikomanagement. Österr. Wasser-Abfallwirtsch. 2018, 70, 316-327. [CrossRef]

129. Thieken, A.H.; Cammerer, H.; Dobler, C.; Lammel, J.; Schöberl, F. Estimating Changes in Flood Risks and Benefits of NonStructural Adaptation Strategies-A Case Study from Tyrol, Austria. Mitig. Adapt. Strateg. Glob. Chang. 2016, 21, 343-376. [CrossRef]

130. Grünewald, U. Von Hochwasser Zu Hochwasser: Eine Herausforderung Nicht Nur Für Die Wasserwirtschaftliche Praxis. Presentation at Fachtagung Hochwasser 2013 in Mitteldeutschland-Ein Jahr nach der Flut-, Dessau, Germany, 17 September 2014. Available online: https:/ / www.dwa-st.de/files/_media/content/PDFs/LV_ST/serv/rueck/fach/2014_hws_1_gruenewald.pdf (accessed on 19 August 2021).

131. International Union for Conservation of Nature. Environment and Disasters. Available online: https://www.iucn.org/theme/ ecosystem-management/our-work/environment-and-disasters (accessed on 9 January 2021).

132. Wahren, A.; Schwärzel, K.; Feger, K.-H. Potentials and Limitations of Natural Flood Retention by Forested Land in Headwater Catchments: Evidence from Experimental and Model Studies: Potentials and Limitations of Natural Flood Retention. J. Flood Risk Manag. 2012, 5, 321-335. [CrossRef]

133. Schmidt, O. Schutz Vor Hochwasser Durch Alpine Berg- Und Schutzwälder-Beiträge Zur Tagung Im Oktober 2017. LWF Wissen 2018, 82, 62 .

134. Andersson-Sköld, Y. Collocation of Experiences with SGI Matrix Based Decision Support Tool (MDST) within SAWA; Swedish Geotechnical Institute: Linköping, Sweden, 2012; p. 627.

135. Evers, M.; Nyberg, L.; Svedung, I. Reducing Flood Risk by Integrative Land Use Planning. In Proceedings of the Land Use Planning and Risk-Informed Decision Making: Proceedings of the 43rd ESReDA Seminar Hosted by INSA Rouen, France; European Commission, Joint Research Centre, Institute for Energy and Transport, Eds.; Publications Office: Luxembourg, $2014 ;$ p. 467.

136. Spreafico, M. Flash Floods in Mountain Areas. In Proceedings of the Climate Variability and Change-Hydrological Impacts, Havana, Cuba, 27 November-1 December 2006; IAHS Publication: Havana, Cuba, 2006; Volume 308, p. 232.

137. Pedersen Zari, M. Biomimetic Materials for Addressing Climate Change. In Handbook of Ecomaterials; Martínez, L.M.T., Kharissova, O.V., Kharisov, B.I., Eds.; Springer International Publishing: Cham, Switzerland, 2018; pp. 1-23, ISBN 978-3-319-48281-1.

138. European Commission. Shoring up Europe's Flood Defences. Available online: https://ec.europa.eu/programmes/horizon202 0/en/news/shoring-europe $\%$ E2\%80\%99s-flood-defences (accessed on 10 September 2021).

139. Engelke, J. Wetlands: A Flooding Solution; Kansas State University: Manhatten, KS, USA, 2012.

140. Thorslund, J.; Jarsjo, J.; Jaramillo, F.; Jawitz, J.W.; Manzoni, S.; Basu, N.B.; Chalov, S.R.; Cohen, M.J.; Creed, I.F.; Goldenberg, R.; et al. Wetlands as Large-Scale Nature-Based Solutions: Status and Challenges for Research, Engineering and Management. Ecol. Eng. 2017, 108, 489-497. [CrossRef]

141. Pfammatter, U. Bauen im Kultur- und Klimawandel: Green Traditions_Clean Future; vdf Hochschulverl: Zurich, Switzerland, 2012; Volume 317, ISBN 978-3-7281-3395-3. 
142. Wantzen, K.M.; Ballouche, A.; Longuet, I.; Bao, I.; Bocoum, H.; Cissé, L.; Chauhan, M.; Girard, P.; Gopal, B.; Kane, A.; et al. River Culture: An Eco-Social Approach to Mitigate the Biological and Cultural Diversity Crisis in Riverscapes. Ecohydrol. Hydrobiol. 2016, 16, 7-18. [CrossRef]

143. Yang, B.; Li, M.-H.; Li, S. Design-with-Nature for Multifunctional Landscapes: Environmental Benefits and Social Barriers in Community Development. Int. J. Environ. Res. Public. Health 2013, 10, 5433-5458. [CrossRef] [PubMed]

144. White, I.; Connelly, A.; Garvin, S.; Lawson, N.; O’Hare, P. Flood Resilience Technology in Europe: Identifying Barriers and Co-Producing Best Practice: Flood Resilience Technology in Europe. J. Flood Risk Manag. 2018, 11, S468-S478. [CrossRef]

145. Schad, I.; Schmitter, P.; Saint-Macary, C.; Neef, A.; Lamers, M.; Nguyen, L.; Hilger, T.; Hoffmann, V. Why Do People Not Learn from Flood Disasters? Evidence from Vietnam's Northwestern Mountains. Nat. Hazards 2012, 62, 221-241. [CrossRef]

146. Priest, S.J.; Suykens, C.; Van Rijswick, H.F.M.W.; Schellenberger, T.; Goytia, S.; Kundzewicz, Z.W.; van Doorn-Hoekveld, W.J.; Beyers, J.-C.; Homewood, S. The European Union Approach to Flood Risk Management and Improving Societal Resilience: Lessons from the Implementation of the Floods Directive in Six European Countries. Ecol. Soc. 2016, 21, art50. [CrossRef]

147. Lumbroso, D.M.; Vinet, F. A Comparison of the Causes, Effects and Aftermaths of the Coastal Flooding of England in 1953 and France in 2010. Nat. Hazards Earth Syst. Sci. 2011, 11, 2321-2333. [CrossRef]

148. Le Roux, B.; Rouanet, H. Geometric Data Analysis: From Correspondence Analysis to Structured Data Analysis; Kluwer Academic Publishers: Dordrecht, The Netherlands; Boston, MA, USA, 2004; ISBN 978-1-4020-2235-7.

149. Le Roux, B.; Rouanet, H. Multiple Correspondence Analysis; SAGE Publications, Inc.: Thousand Oaks, CA, USA, 2010; Volume 163, ISBN 978-1-4129-6897-3.

150. Robette, N. Package "GDAtools"; 17 May 2020. Available online: nicolas.robette.free.fr/outils_eng.html (accessed on 19 August 2021).

151. Döring, N.; Bortz, J. Forschungsmethoden und Evaluation in den Sozial- und Humanwissenschaften; Springer-Lehrbuch, 5. Vollständig überarbeitete Aktualisierte und Erweiterte Auflage; Springer: Berlin/Heidelberg, Germany, 2016; ISBN 978-3-642-41089-5.

152. Andersson-Sköld, Y.; Nyberg, L. Effective and Sustainable Flood and Landslide Risk Reduction Measures: An Investigation of Two Assessment Frameworks. Int. J. Disaster Risk Sci. 2016, 7, 374-392. [CrossRef]

153. Ballesteros-Cánovas, J.A.; Czajka, B.; Janecka, K.; Lempa, M.; Kaczka, R.J.; Stoffel, M. Flash Floods in the Tatra Mountain Streams: Frequency and Triggers. Sci. Total Environ. 2015, 511, 639-648. [CrossRef]

154. Bathurst, J.C.; Iroumé, A.; Cisneros, F.; Fallas, J.; Iturraspe, R.; Novillo, M.G.; Urciuolo, A.; de Bièvre, B.; Borges, V.G.; Coello, C.; et al. Forest Impact on Floods Due to Extreme Rainfall and Snowmelt in Four Latin American Environments 1: Field Data Analysis. J. Hydrol. 2011, 400, 281-291. [CrossRef]

155. Bianchin, S. Feldhecken und deren Einfluss auf Hochwasser und Naturschutz unter Berücksichtigung von Agrarökonomischen Belangen im Naturraum Erzgebirge; Technische Universität Bergakademie Freiberg: Freiberg, Germany, 2012.

156. Biron, P.M.; Buffin-Bélanger, T.; Larocque, M.; Choné, G.; Cloutier, C.-A.; Ouellet, M.-A.; Demers, S.; Olsen, T.; Desjarlais, C.; Eyquem, J. Freedom Space for Rivers: A Sustainable Management Approach to Enhance River Resilience. Environ. Manag. 2014, 54, 1056-1073. [CrossRef] [PubMed]

157. Bullock, A.; Acreman, M. The Role of Wetlands in the Hydrological Cycle. Hydrol. Earth Syst. Sci. 2003, 7, 358-389. [CrossRef]

158. Burby, R.J.; French, S.P. Coping With Floods: The Land Use Management Paradox. J. Am. Plann. Assoc. 1981, 47, 289-300. [CrossRef]

159. Bwambale, B.; Muhumuza, M.; Nyeko, M. Traditional Ecological Knowledge and Flood Risk Management: A Preliminary Case Study of the Rwenzori. Jàmbá J. Disaster Risk Stud. 2018, 10, 1-10. [CrossRef] [PubMed]

160. Cao, F.; Tao, Q.; Dong, S.; Li, X. Influence of Rain Pattern on Flood Control in Mountain Creek Areas: A Case Study of Northern Zhejiang. Appl. Water Sci. 2020, 10, 224. [CrossRef]

161. European Commission. Annex: Towards Better Environmental Options for Flood Risk Management; European Commission: Brussels, Belgium, 2011; p. 16.

162. Ferk, M.; Ciglič, R.; Komac, B.; Loczy, D. Management of Small Retention Ponds and Their Impact on Flood Hazard Prevention in the Slovenske Gorice Hills. Acta Geogr. Slov. 2020, 60, 107-125. [CrossRef]

163. Fuchs, S.; Heiser, M.; Schlögl, M.; Zischg, A.; Papathoma-Köhle, M.; Keiler, M. Short Communication: A Model to Predict Flood Loss in Mountain Areas. Environ. Model. Softw. 2019, 117, 176-180. [CrossRef]

164. González-Arqueros, M.L.; Mendoza, M.E.; Bocco, G.; Solís Castillo, B. Flood Susceptibility in Rural Settlements in Remote Zones: The Case of a Mountainous Basin in the Sierra-Costa Region of Michoacán, Mexico. J. Environ. Manag. 2018, 223, 685-693. [CrossRef]

165. Hall, J.; Arheimer, B.; Borga, M.; Brázdil, R.; Claps, P.; Kiss, A.; Kjeldsen, T.R.; Kriaučiūnienė, J.; Kundzewicz, Z.W.; Lang, M.; et al. Understanding Flood Regime Changes in Europe: A State-of-the-Art Assessment. Hydrol. Earth Syst. Sci. 2014, 18, $2735-2772$. [CrossRef]

166. Harder, P.; Pomeroy, J.W.; Westbrook, C.J. Hydrological Resilience of a Canadian Rockies Headwaters Basin Subject to Changing Climate, Extreme Weather, and Forest Management: Hydrological Resilience of a Canadian Rockies Basin Subject to Change. Hydrol. Process. 2015, 29, 3905-3924. [CrossRef]

167. Harry, I.; Assmann, T.; Rietze, J.; Trautner, J. Der Hochmoorlaufkäfer Carabus Ménétriesi Im Vor-Alpinen Moor-Und Hügelland Bayerns. Angew. Carabidol. 2005, 4, 53-64. 
168. freshideen.com. Geniales Haus Design Bietet Schtz Vor Überschwemmung. Available online: https://freshideen.com/ architektur/geniales-haus-design.html (accessed on 27 January 2021).

169. Helmrich, A.M.; Chester, M.V.; Hayes, S.; Markolf, S.A.; Desha, C.; Grimm, N.B. Using Biomimicry to Support Resilient Infrastructure Design. Earths Future 2020, 8. [CrossRef]

170. Izmaiłow, B.; Kamykowska, M.; Krzemień, K. The Geomorphological Effects of Flash Floods in Mountain River Channels. The Case of the River Wilsznia (Western Carpathian Mountains). Pr. Geogr. 2006, 116, 89-102.

171. Thomas, K. Dezentrale Und Naturnahe Retentionsmaßnahmen Als Beitrag Zum Hochwasserschutz in Mesoskaligen Einzugsgebieten Der Mittelgebirge; Universität Trier: Trier, Germany, 2006.

172. Ley, R. Der Einfluss Kleiner Naturnaher Retentionsmaßnahmen in Der Fläche Auf Den Hochwasserabfluss-Kleinrückhaltebecken-; Diplomarbeit, Universität Trier, FB VI, Physische Geographie: Trier, Germany, 2006.

173. List, G.; Laszlo, S.; Coomes, O.T. Mitigating Risk for Floodplain Agriculture in Amazonia: A Role for Index-Based Flood Insurance. Clim. Dev. 2020, 12, 649-663. [CrossRef]

174. Mascarenhas, F.; Miguez, M.; Magalhães, L. Multifunctional Landscapes for Urban Flood Control in Developing Countries. In Proceedings of the Transactions of the Second International Conference on Sustainable Development and Planning, Bologna, Italy, 12-14 September 2005; WIT Press: Southampton, UK, 2005; Volume 2, pp. 1579-1588.

175. Ministry of Land Infrastructure Transport and Tourism Water and Disaster Management Bureau (Japan), "MLIT". Available online: https:/ / www.mlit.go.jp/en/mizukokudo/index.html (accessed on 13 January 2021).

176. O'Connell, P.E.; Ewen, J.; O’Donnell, G.; Quinn, P. Is There a Link between Agricultural Land-Use Management and Flooding? Hydrol. Earth Syst. Sci. 2007, 11, 96-107. [CrossRef]

177. Piana, P.; Faccini, F.; Luino, F.; Paliaga, G.; Sacchini, A.; Watkins, C. Geomorphological Landscape Research and Flood Management in a Heavily Modified Tyrrhenian Catchment. Sustainability 2019, 11, 4594. [CrossRef]

178. Radecki-Pawlik, A.; Plesiński, K.; Radecki-Pawlik, B.; Kuboń, P.; Manson, R. Hydrodynamic Parameters in a Flood Impacted Boulder Block Ramp: Krzczonówka Mountain Stream, Polish Carpathians. J. Mt. Sci. 2018, 15, 2335-2346. [CrossRef]

179. Radulescu, D.; Ion, M.B.; Dumitrache, R.; Barbu, C.E. Flood Risk Management Objectives and Romanian Catalogue of Potential Measures for Flood Prevention, Protection and Mitigation. E3S Web Conf. 2016, 7, 23001. [CrossRef]

180. Ran, J.; Nedovic-Budic, Z. Integrating Spatial Planning and Flood Risk Management: A New Conceptual Framework for the Spatially Integrated Policy Infrastructure. Comput. Environ. Urban Syst. 2016, 57, 68-79. [CrossRef]

181. Rawat, P.K.; Tiwari, P.C.; Pant, C.C. Geo-Hydrological Database Modeling for Integrated Multiple Hazards and Risk Assessment in Lesser Himalaya: A GIS-Based Case Study. Nat. Hazards 2012, 62, 1233-1260. [CrossRef]

182. Richert, E.; Bianchin, S.; Heilmeier, H.; Merta, M.; Seidler, C. Flood Prevention and Nature Conservation in the Weisseritz Area (Eastern Erzgebirge, Saxony, Germany), Interdisciplinary Evaluation of Land Use Scenarios. In Proceedings of the Flood Prevention and Nature Conservation -Interdisciplinary Evaluation of Land Use Scenarios for an Agricultural Landscape; Střelcová, K., Mátyás, C., Kleidon, A., Lapin, M., Matejka, F., Blaženec, M., Škvarenina, J., Holécy, J., Eds.; Springer: Dordrecht, The Netherlands, 2009; pp. 137-141.

183. Rieger, W. Prozessorientierte Modellierung dezentraler Hochwasserschutzmaßnahmen; Mitteilungen/Universität der Bundeswehr: München, Germany; Institut für Wasserwesen: München, Germany; Shaker: Aachen, Germany, 2012; ISBN 978-3-8440-1209-5.

184. Ruiz-Villanueva, V.; Díez-Herrero, A.; Bodoque, J.M.; Ballesteros Cánovas, J.A.; Stoffel, M. Characterisation of Flash Floods in Small Ungauged Mountain Basins of Central Spain Using an Integrated Approach. CATENA 2013, 110, 32-43. [CrossRef]

185. Salazar, S.; Francés, F.; Komma, J.; Blöschl, G.; Blume, T.; Francke, T.; Bronstert, A. Efficiency of Non-Structural Flood Mitigation Measures:"Room for the River" and "Retaining Water in the Landscape". In Proceedings of the Flood Risk Management: Research and Practice, Oxford, UK, 30 September-2 October 2008; Samuels, P., Ed.; Taylor \& Francis Group: London, UK; Oxford, UK, 2009; pp. 723-731.

186. Schindler, S.; O’Neill, F.H.; Biró, M.; Damm, C.; Gasso, V.; Kanka, R.; van der Sluis, T.; Krug, A.; Lauwaars, S.G.; Sebesvari, Z.; et al. Multifunctional Floodplain Management and Biodiversity Effects: A Knowledge Synthesis for Six European Countries. Biodivers. Conserv. 2016, 25, 1349-1382. [CrossRef]

187. Sieker, F.; Wilcke, D.; van der Ploeg, R. Innovativer Ansatz Eines Vorbeugenden Hochwasserschutzes Durch Dezentrale Maßnahmen Im Bereich Der Siedlungswasserwirtschaft Sowie Der Landwirtschaft Im Einzugsgebiet Der Lausitzer Neiße; Hannover University, Deutsche Bundesstiftung Umwelt: Hannover Osnabrück, Germany, 2002.

188. Smith, P.; Nkem, J.; Calvin, K.; Campbell, D.; Cherubini, F.; Grassi, G.; Korotkov, V.; Hoang, A.; Lwasa, S.; McElwee, P.; et al Interlinkages between Desertification, Land Degradation, Food Security and Greenhouse Gas Fluxes: Synergies, Trade-Offs and Integrated Response Options; Climate Change and Land: An IPCC Special Report on Climate Change, Desertification, Land Degradation, Sustainable Land Management, Food Security, and Greenhouse Gas Fluxes in Terrestrial Ecosystems; The Intergovernmental Panel on Climate Change IPCC: Geneva, Switzerland, 2019; p. 122.

189. Pharo, P.; Oppenheim, J. Growing Better: Ten Critical Transitions to Transform Food and Land Use. Food and Land Use Coalition London FOLU, Report. 2019. Available online: https:/ / www.foodandlandusecoalition.org/wp-content/uploads/2019/09/FOLUGrowingBetter-GlobalReport.pdf (accessed on 19 August 2021).

190. Smith, P.; Calvin, K.; Nkem, J.; Campbell, D.; Cherubini, F.; Grassi, G.; Korotkov, V.; Le Hoang, A.; Lwasa, S.; McElwee, P.; et al Which Practices Co-deliver Food Security, Climate Change Mitigation and Adaptation, and Combat Land Degradation and Desertification? Glob. Chang. Biol. 2020, 26, 1532-1575. [CrossRef] 
191. Tan, L.; Ge, Z.; Zhou, X.; Li, S.; Li, X.; Tang, J. Conversion of Coastal Wetlands, Riparian Wetlands, and Peatlands Increases Greenhouse Gas Emissions: A Global Meta-Analysis. Glob. Chang. Biol. 2020, 26, 1638-1653. [CrossRef]

192. Teschemacher, S.; Neumayer, M.; Disse, M.; Rieger, W. Retentionspotenzial von Aufforstungsmaßnahmen in Einem Voralpinen Einzugsgebiet. LWF Wissen 2017, 82, 11-18.

193. Thigpen, J. Strategy for a Flood Resistant Southern Tier Central Region. Municipal Land Use Strategies for Improving Flood Resilience. Guidance for Protecting Health, Safety, and Welfare; Southern Tier Central Regional Planning \& Development Board: New York, NY, USA, 2017; p. 56.

194. Wajih, S.A. Adaptive Agriculture in Flood Affected Areas. LEISA Mag. 2008, 24, 24-25.

195. Wells, J.A.; Wilson, K.A.; Abram, N.K.; Nunn, M.; Gaveau, D.L.A.; Runting, R.K.; Tarniati, N.; Mengersen, K.L.; Meijaard, E. Rising Floodwaters: Mapping Impacts and Perceptions of Flooding in Indonesian Borneo. Environ. Res. Lett. 2016, 11, 064016. [CrossRef]

196. Van Steenbergen, F. Six Ways to Increase Productivity of Flood-Based Farming Systems. Available online: https://wle.cgiar.org/ solutions/six-ways-increase-productivity-flood-based-farming-systems (accessed on 12 January 2021).

197. Yong, T.; Bingshun, H.; Minghua, C.; Qing, L.; Qingrui, C. Characteristics of Mountain Flood Disasters in 2013. China Water Resour. 2014, 2014, 6.

198. Zhao, G.; Pang, B.; Xu, Z.; Yue, J.; Tu, T. Mapping Flood Susceptibility in Mountainous Areas on a National Scale in China. Sci. Total Environ. 2018, 615, 1133-1142. [CrossRef] [PubMed]

199. Avon Wildlife Trust. North Somerset Levels and Moors Partnership Project. Available online: https://oppla.eu/casestudy/19191 (accessed on 10 September 2021).

200. Förster, S.; Kuhlmann, B.; Lindenschmidt, K.-E.; Bronstert, A. Assessing Flood Risk for a Rural Detention Area. Nat. Hazards Earth Syst. Sci. 2008, 8, 311-322. [CrossRef]

201. Liquete, C.; Udias, A.; Conte, G.; Grizzetti, B.; Masi, F. Integrated Valuation of a Nature-Based Solution for Water Pollution Control. Highlighting Hidden Benefits. Ecosyst. Serv. 2016, 22, 392-401. [CrossRef]

202. McLean, L.; Beevers, L.; Pender, G.; Haynes, H.; Wilkinson, M. Natural Flood Management in the UK: Developing a Conceptual Management Tool. In Proceedings of the 35th IAHR World Congress, Chengdu, China, 8-13 September 2013; Tsinghua University Press: Beijing, China, 2013; p. 12.

203. Somarakis, G.; Stagakis, S.; Chrysoulakis, N. (Eds.) ThinkNature/Nature-Based Solutions Handbook; ThinkNature Project Funded by the EU Horizon 2020 Research and Innovation Programme under Grant Agreement No. 730338. Foundation for Research and Technology-Hellas, FORTH. 2019. Available online: https://doi.org/10.26225/JERV-W202 (accessed on 19 August 2021). [CrossRef]

204. Sayers, P.; Galloway, G.; Penning-Rowsell, E.; Yuanyuan, L.; Fuxin, S.; Yiwei, C.; Kang, W.; Le Quesne, T.; Wang, L.; Guan, Y. Strategic Flood Management: Ten 'Golden Rules' to Guide a Sound Approach. Int. J. River Basin Manag. 2015, 13, 137-151. [CrossRef]

205. Sieker, F.; Wilcke, D.; Reich, M.; Rüter, S.; Jasper, J.; Salzmann, M.; Schmidt, W.; Zacharias, S.; Nitzsche, O. Vorbeugender Hochwasserschutz Durch Wasserrückhalt in Der Fläche Unter Besonderer Berücksichtigung Naturschutzfachlicher Aspekte-Am Beispiel Des Flusseinzugsgebietes Der Mulde in Sachsen; Institut für Wasserwirtschaft, Hydrologie und landwirtschaftlichen Wasserbau der Leibniz Universität Hannover, Deutsche Bundesstiftung Umwelt: Hannover, Germany, 2007.

206. Gabalda, V.; Hunter, K.; Florence, C.; Salagnac, J.-L.; Golz, S.; ten Veldhuis, M.-C.; Diez, J.; Monnot, J.V. Flood Resilience Technologies; Deliverable of the EU-FP7 Research Project SMARTeST—Smart Resilience Technology, Systems and Tools. 2013. Available online: https:/ / www.floodguidance.co.uk/wp-content/uploads/2017/10/D2.3-final-July13.pdf (accessed on 19 August 2021).

207. Thieken, A.H.; Kienzler, S.; Kreibich, H.; Kuhlicke, C.; Kunz, M.; Mühr, B.; Müller, M.; Otto, A.; Petrow, T.; Pisi, S.; et al. Review of the Flood Risk Management System in Germany after the Major Flood in 2013. Ecol. Soc. 2016, 21, art51. [CrossRef]

208. Evers, M.; Arndt, P.; Mußbach, J.; Tischbierick, M. Instrument(s) for Integrated Flood Risk Management. Presentation at Leuphana Universität Lüneburg. 2011. Available online: https:/ / docplayer.org/4073526-Instrument-s-for-integrated-flood-riskmanagement.html (accessed on 19 August 2021).

209. Tussig, K.; Bräunig, A.; Siemer, B.; Schmidt, W.; Worm, W. Dezentraler Hochwasserschutz Im Ländlichen Raum (2.Auflage); Sächsisches Landesamt für Umwelt, Landwirtschaft und Geologie, Dresden, Germany. 2016. Available online: https:// publikationen.sachsen.de/bdb/artikel/13555 (accessed on 19 August 2021).

210. Fa, J.E.; Watson, J.E.; Leiper, I.; Potapov, P.; Evans, T.D.; Burgess, N.D.; Molnár, Z.; Fernández-Llamazares, Á.; Duncan, T.; Wang, S.; et al. Importance of Indigenous Peoples' Lands for the Conservation of Intact Forest Landscapes. Front. Ecol. Environ. 2020, 18, 135-140. [CrossRef]

211. Garnett, S.T.; Burgess, N.D.; Fa, J.E.; Fernández-Llamazares, Á.; Molnár, Z.; Robinson, C.J.; Watson, J.E.M.; Zander, K.K.; Austin, B.; Brondizio, E.S.; et al. A Spatial Overview of the Global Importance of Indigenous Lands for Conservation. Nat. Sustain. 2018, 1, 369-374. [CrossRef]

212. Guida, R.J.; Swanson, T.L.; Remo, J.W.F.; Kiss, T. Strategic Floodplain Reconnection for the Lower Tisza River, Hungary: Opportunities for Flood-Height Reduction and Floodplain-Wetland Reconnection. J. Hydrol. 2015, 521, 274-285. [CrossRef]

213. Mes, J.; Reichart, N. Dike monitoring: Improving insight in actual strength of embankments. Water Matters Knowl. J. Water Prof. 2015, 2, 1. Available online: https:/ / www.h2o-watermatters.com/includes / partials / printArticle.php?ed=201511\&art=01_Artikel (accessed on 19 August 2021). 
214. Kousky, C.; Olmstead, S.M.; Walls, M.A.; Macauley, M. Strategically Placing Green Infrastructure: Cost-Effective Land Conservation in the Floodplain. Environ. Sci. Technol. 2013, 47, 3563-3570. [CrossRef]

215. Rouquette, J.R.; Posthumus, H.; Morris, J.; Hess, T.M.; Dawson, Q.L.; Gowing, D.J.G. Synergies and Trade-Offs in the Management of Lowland Rural Floodplains: An Ecosystem Services Approach. Hydrol. Sci. J. 2011, 56, 1566-1581. [CrossRef]

216. Shaw, R. Critical Issues of Community Based Flood Mitigation: Examples from Bangladesh and Vietnam. J. Sci. Cult. 2006, 72, 62.

217. Simm, J.; Meadowcroft, I. Performance of Flood Risk Management Measures-COMRISK Subproject 4. In Die Küste; HENRY Hydraulic Engineering Repository_Ein Service der Bundesanstalt für Wasserbau; Boyens: Heide, Holstein, Germany, 2005; pp. $47-56$.

218. United Nations; UNISDR; UNDP; IUCN. Making Disaster Risk Reduction Gender Sensitive: Policy and Practical Guidelines; UNISDR, UNDP: New York, NY, USA; IUCN: Gland, Switzerland; Geneva, Switzerland, June 2009; p. 163. Available online: https: //www.unisdr.org/files/9922_MakingDisasterRiskReductionGenderSe.pdf (accessed on 19 August 2021).

219. Walker, W.S.; Gorelik, S.R.; Baccini, A.; Aragon-Osejo, J.L.; Josse, C.; Meyer, C.; Macedo, M.N.; Augusto, C.; Rios, S.; Katan, T.; et al. The Role of Forest Conversion, Degradation, and Disturbance in the Carbon Dynamics of Amazon Indigenous Territories and Protected Areas. Proc. Natl. Acad. Sci. USA 2020, 117, 3015-3025. [CrossRef] [PubMed] 